\title{
Stock Market Linkages and Spillover Effects: An Empirical Analysis of Select Asian Markets
}

\author{
Sanjay Sehgal1, Kumar Bijoy ${ }^{2 *}$, Sakshi Saini ${ }^{1}$ \\ ${ }^{1}$ Department of Financial Studies, University of Delhi, Delhi, India \\ ${ }^{2}$ Shaheed Sukhdev College of Business Studies, University of Delhi, Delhi, India \\ Email: sanjayfin15@y ahoo.co.in, ${ }^{*}$ kumarbijoy@ssdsdu.ac.in, s.sakshi1408@gmail.com
}

How to cite this paper: Sehgal, S., Bijoy, K. and Saini, S. (2019) Stock Market Linkages and Spillover Effects: An Empirical Analysis of Select Asian Markets. Theoretical Economics Letters, 9, 1447-1472.

https://doi.org/10.4236/tel.2019.95093

Received: March 1, 2019

Accepted: June 16, 2019

Published: June 19, 2019

Copyright $\odot 2019$ by author(s) and Scientific Research Publishing Inc. This work is licensed under the Creative Commons Attribution International License (CC BY 4.0).

http://creativecommons.org/licenses/by/4.0/

\section{(c) (i) Open Access}

\begin{abstract}
This study tries to find the dynamic stock market linkages among 12 Asian countries over the period January 3, 2000 to June 20, 2017. We employ ADCC-GARCH model to study the conditional correlations and Diebold and Yilmaz (2012) spillover index methodology to investigate return and volatility spillovers across the sample markets [1]. Based on ADCC results, we find that Singapore exhibits highest conditional correlation with other sample markets. Dynamic conditional correlations across the markets amplify during the crisis periods, pointing to financial contagion. The findings under Diebold-Yilmaz framework corroborate with the ADCC-GARCH model results as Singapore is found to be the dominant market based on both return and volatility spillovers. Inter-temporal pattern of spillovers reveals that cross-market linkages intensify during the turmoil periods. Our results have important implications for international investors and policymakers. The study contributes to financial integration literature for Asian markets.
\end{abstract}

\section{Keywords}

Asian Stock Markets, ADCC-GARCH, Chinese Meltdown, Diebold-Yilmaz, Return Spillover, Volatility Spillover

\section{Introduction}

By 1980s it became an accepted fact that the prerequisites for growth of any economy are: an orientation towards world trade; liberalization of the domestic economy along with fiscal and monetary prudence. Most of the Asian economies opened up on these believes and witnessed high growth rate of the economy on sustainable basisas mentioned in the East Asian miracle by the [2]. However, [3] questioned the sustainability of the economic boom in East Asia as in his opi- 
nion in the absence of technical progress the growth will not be able to sustain in the long-run. Krugman's observations were viewed by the economists as predictor of the severe Asian financial crisis in 1997. Similar concern was raised by the Japanese government as they criticized the World Bank for overemphasizing macroeconomic stability. The Bank argued in response to the Japanese challenge that three factors have been key in the East Asian economic miracle. The first was macroeconomic stability, which is to say: low inflation, prudent budget deficits, and stable and competitive exchange rates. The second was heavy public investment in education and other social infrastructure like health. The third was an emphasis on exports as the "standard by which all economic activity would be judged".

After experiencing high GDP growth rate during 1970s and 80s from $6.9 \%$ in Indonesia to $8.4 \%$ in Korea, symptoms of fundamental deficiencies started getting visible. Macroeconomic weaknesses finally led to the currency meltdown in Thailand in 1997 which scaled-up to a financial turmoil in the region. It further spread beyond the region to Russia and Brazil in 1998 [4]. To overcome the impact of this crisis, East Asian economies shifted the focus on strengthening their economic and financial fundamentals, by initiating a number of regional cooperation programs and policies which in due course saved them from the global financial crisis in 2007.

Asia-Pacific is leading the recovery in world trade. In 2016, Asia's trade (by volume) growth was higher than that of global trade growth, but unable to beat its own economic growth. This is evident from the fact that Asia's trade growth increased from $1.4 \%$ (2015) to $1.7 \%$ (2016) whereas the world trade growth decelerated to $1.3 \%$ from $2.6 \%$ for the corresponding period. The trade volume growth in Asia was more than 61\% (\$2.78 $\mathrm{t}$ in 2005 to $\$ 4.5 \mathrm{t}$ in 2016) as compared to global trade volume growth which was about 52\% ( $\$ 10.16 \mathrm{t}$ to $\$ 15.5 \mathrm{t}$ during same 2005 to 2016 period). Intraregional trade value share of Asia has marginally increased up to $57.3 \%$ in 2016 up from an average $55.9 \%$ during 2010-2015. Global economic recovery has a positive impact on the region's exports in general, whereas Japan; Taiwan; Hong Kong; and Vietnam are prominent beneficiary. On the other side increased demand from China, India and others have contributed towards the increase in region's import. The recent data on Asia's trade growth indicate its further acceleration to $7.4 \%$ during the first half of 2017 which may continue in future.

The Asian growth is also evident from the fact that FDI in the region used to come mainly from Western countries in the past and intra-regional FDI (within Asia) was only $36 \%$ during $2006-09$. However, this increased to $52 \%$ during post crisis periods (2010-15). Among the Asian sub regions East and South East Asia was commanding $84 \%$ of total intra-regional $\mathrm{FDI}^{1}$. Volume wise intra-regional (Asia Pacific Economic cooperation) FDI increased from $\$ 7 \mathrm{t}(44 \%)$ to $\$ 10 \mathrm{t}$ (48\%) during 2010-15 period. Asia’s total FDI inflow in 2016 was $\$ 443 \mathrm{~b}(25.3 \%$ ${ }^{1}$ Flows which was further concentrated in East Asia (60\%) and South East Asia (24\%) as per 2015 statistics (Asian Economic Integration Report by [52]. 
of world FDI inflow) whereas outflow during the same period was $\$ 363 \mathrm{~b}$ (25\% of world FDI outflow). Intraregional share of FDI has also grown from $47.6 \%$ (2015) to 55.3\% (2016) and cross-border bank claims of Asia also increased to $\$ 4.4$ trillion from $\$ 4.1$ trillion for the same period (2015 to 2016). This has made developing Asia emerge as the second largest recipient of FDI in the world with Chinese Mainland, Hong Kong China, Singapore and India ranking among top 10 FDI host economies. A positive economic outlook is expected to further improve FDI inflows in Asian market especially in China and South Asia in future [5]. Stock markets in Asia Pacific have performed exceedingly well compared to other world Stock markets in 2017. The MSCI All Country Asia Pacific Index (MSCI AC Asia Pacific) gained $29 \%$ as against $22.6 \%$ by MSCI All Country World Index (MSCI ACWI) in the first eleven months of 2017.

The studies by [6] [7] [8] [9] conclude that Asian markets have been relatively less integrated with western economies leading to an opportunity for global diversification. However, Asian markets are gradually getting integrated with western markets which became very prominent during the global financial crisis (2007-09). This trend is evident from recent studies on market integration by [10] [11]-[17].

The volatility of Asian equity market returns is explained more by variations in global than regional equity market returns and this trend is getting further more prominent from 2015 onwards. This supports relatively higher integration of Asia's equity markets with global market than regional one [18]. Portfolio investors of Asia kept on investing more outside than within the region which is evident from more than $9 \%$ increment in outward equity investment outstanding from 2015 to 2016 (from $\$ 3.2$ trillion in 2015 to $\$ 3.5$ trillion in 2016). This persistent outward bias of Asia's portfolio investment has led to $1 \%$ decrease in intraregional outward equity investment share (19\% in 2016 compared to $20 \%$ in 2015).

There are 60 major stock exchanges in the world with total market capitalization of $\$ 76.3 \mathrm{t}$ as on 2016 out of which 16 stock exchanges are of more than $\$ 1 \mathrm{t}$ each accounting for $87 \%$ of the total global stock market capitalization. Asia has 17 major stock exchanges with total market capitalization of more than $\$ 23.05 \mathrm{t}$ which is about $30 \%$ of the world market. Among Asian stock markets Japan is the biggest with the market cap of $\$ 4.91 \mathrm{t}$ followed by Shanghai Stock Exchange having value of $\$ 4.46 \mathrm{t}$.

From the above facts one can clearly see the growing role and importance of Asia in world business and also that Asia's intraregional trade and investment is getting strengthen compared to its inter regional trade and investment with other world economy. The stronger economic and trade integration should get reflected in greater dynamic interactions among Asian financial markets, particularly the stock market movements which are highly sensitive to macroeconomic fundamentals. In other words, the real economy linkages must translate into financial economy linkages. The growing global portfolio management activities should also result in greater information transmission among the financial mar- 
kets. Hence, a comprehensive study of dynamic stock market linkages in the Asian region is of critical importance not only for policy makers but also for academicians as well as market participants.

The present study aims to explore the financial integration through information spillover effects amongst Asian stock markets. It specifically examines the following research questions: a) what is the level of integration amongst select Asian stock markets? b) How have the associations changed dynamically during Pre-crisis, Crisis and Post-crisis periods? c) Which are the dominant players and satellite markets in this region? d) Does the relative dominance vary for mean and volatility spillovers? We employ ADCC-GARCH model to study the conditional correlations and Diebold and Yilmaz (2012) spillover index methodology to investigate return and volatility spillovers across the sample markets. Based on ADCC results, we find that Singapore exhibits highest conditional correlations with other sample markets, while Pakistan exhibits least association with the sample stock markets. Dynamic conditional correlations across the markets amplify during the crisis period, pointing to financial contagion. Chinese meltdown also seems to impact the Asian markets owing to their regional proximity and economic and trade relations with China as is reflected in their heightened associations during this period. The findings under Diebold-Yilmaz framework corroborate with the ADCC-GARCH model results as Singapore is found to be the dominant market based on both return and volatility spillovers. India is found to be a major net transmitter of volatility spillovers to other Asian markets along with exhibiting relatively high gross spillovers. Inter-temporal pattern of spillovers reveal cross-market linkages intensify during the turmoil periods.

The remaining part of the study is organized as follows: Section 2 provides a brief review of literature on stock market linkages in Asia. Section 3 presents data whereas methodology is in Section 4. The empirical results and discussion are provided in Section 5, while Section 6 contains summary and conclusions.

\section{Review of Literature}

Review of previous studies indicates that the Post Asian Crisis period witnessed increase in correlations among Asian markets and thus attracted attention of empirical researchers. [19] [20] [21] are prominent studies which discuss the Asian market linkages during Asian financial crisis. Worthington and Higgs [22] examine these transmissions among Asian equity markets and investigate the differences that exist in this regard between the developed and emerging markets using MGARCH model. The results indicate the existence of large mean and volatility spillovers positively related. The direction of mean spillovers is from the developed markets to the emerging markets, however, they are not homogeneous across the later group. Their findings also indicate that cross-volatility spillovers are lower than that of own-volatility spillovers for all markets in general and for the emerging markets in particular. Majid, et al. [23] explore market integration among five selected ASEAN markets (Malaysia, Thailand, Indonesia, Philippines and Singapore) during the pre- and post-1997 financial crisis periods 
using co-integration technique on daily data from January 1988 to Dec 2006 and find the stock markets in the ASEAN region have co-integration throughout the pre- and post-1997 financial crisis but it is gradually increasing during the post-1997 financial crisis period.

A number of studies in last two decades also examine the returns and volatility linkages amongst Asian equity markets during global financial crisis (GFC) and compare them with pre and post GFC periods. [15] tests the presence of dynamic nature of volatility contagion in the Asia-Pacific region around the global financial crisis of 2007-2008 by using multivariate GARCH approach and tries to estimate its possible impact on potential investors in the region. His study evidences the significant intra-regional volatility spillover during the period of June 2006-December 2010 among selected eight Asia-Pacific economies, however, its nature is dependent on the global stock price movements. It is further noticed that pre and post global financial crisis periods have similar features which are different from that of crisis period. His study also observes that in the boom period spillover effect is low which gets intensified during crisis period. [24] examines the return and volatility spillover using daily closing prices for indices of six Asian equity markets namely Chinese Mainland, Hong Kong China, India, Indonesia, Japan, and South Korea. He uses an MGARCH-BEKK and finds that the return, shock, and volatility spillover among most of the stock markets are bidirectional. His findings suggest that own volatility spillover is more than cross-market spillover. [25] in his study tries to find the interlink ages of stock return behavior of China with three emerging markets of Asia namely Philippines, Thailand and Indonesia on the monthly data from 1993 to $2008 \mathrm{im}$ plying VAR model. The findings support the spillovers from China to other equity markets. [26] in their study of nine emerging and advanced Asian stock market integration, using Johansen and Juselius multivariate cointegration test, Granger causality/Block exogeneity Wald test based on the vector error correction model (VECM) approach, and variance decomposition analysis on daily data for January 2000 to January 2013, find the long run equilibrium relationship among these markets. That means investors may use these markets for portfolio diversification in short run [27]. Wang (2013) in his study for daily closing prices of stock market index from East Asian countries using multivariate VAR analysis finds that the linkages among stock markets in East Asia got strengthened post global financial crisis. As per his findings stock markets of Hong Kong China and Singapore are losing their influence whereas that of South Korea and Japan are gaining their importance in the region with the progress of time. Interestingly, his findings further suggest that East Asian stock markets are less responsive to the post crisis shocks from the USA [28]. In his study explores dynamic linkages between Stock market of Pakistan and select five Asian countries on monthly closing stock prices indices for the period of 2003 to 2013 by using Johansen and Juselius co-integration approach and Granger Causality test. His findings suggest no long run relationship between Pakistan and select Asian stock markets. He also uses variance decomposition analysis 
and concludes that variances in stock markets of Pakistan and India are due to their own market innovation and have no influence from other markets. [29] examines the pattern and causes of emerging Asian stock market integration for China, India, Korea, Thailand, Malaysia and Singapore with US and Australia from January 2001 to March 2012. Using GARCH-DCC model, they find the strongest correlation during the global financial crisis (2007-09) period. They consider the GFC and the underlying economic \& financial conditions responsible for higher correlations amongst these stock markets [30]. In his study of ten equity markets of East Asian countries from 1995 to 2011 covering both crises i.e. Asian currency crisis and global financial crisis. He finds link ages among the select markets through significant spatial effects. He further shows that crises increase cross-border associations among the select markets especially in China, and Japan who are the dominant leaders of market linkages in the region [31]. In their study on weekly data of January 1992 to January 2013 belonging to China and ASEAN-5 countries check the dynamic process of convergence among the selected cross-border stock markets using recursive co-integration analysis. The results show that these six stock markets are co-integrated. Overall, the regional financial integration between China and ASEAN-5 has gradually increased. [32] attempts to find contagion amongst the Asia-Pacific equity markets (Japan, Hong Kong China and Australia) at the time of crisis periods and evaluate the impact during past twelve major crisis periods around the world. It is interesting to note that shocks are transmitted via excessive linkages, with the Asian crisis as the most influential one. They further find that the subprime crisis reveals fundamentals-based contagion, due to the strengthening fundamental linkages, with a dominant role of the Japanese market [33]. In their study find that select six Asian equity markets are co-integrated in long run and their volatility dynamics changes as the extent of the spillovers increase. By using wavelet multiple correlation and cross-correlation on the data from 2000 to 2013 they further find that volatility spillover across the considered market is comparatively low at the high frequency creating an opportunity for diversification for shorter period which diminishes in long run [34]. In their study on five emerging Asian markets in pre and post 2007 financial crisis period about the volatility spillover effects using an extended EGARCH model on the daily data of 2001 to 2013 find mixed results. They observed bidirectional volatility spillover between stock markets of India and Sri Lanka in both sub-periods; whereas it is bidirectional between stock markets of India with Hong Kong China and India with Pakistan in pre-crisis period. On the other hand stock markets of Sri Lanka and Pakistan have bidirectional volatility spillover in post-crisis period [35]. By using conditional nonlinear quantile regression on the daily stock index returns for the period of January 1990 to December 2012, show that the stock market co-movements in the Pacific Basin region are due to pairwise similarities of a set of macroeconomic variables among major countries in the region. The findings suggest that smaller pairwise differences or larger pairwise similarities of a set of macroeconomic variables significantly drive the stock market co-movements in the region 
in a nonlinear way [36]. Use Copula GARCH models to study the intertemporal process of equity market integration for the ASEAN+6 countries i.e. East Asia Economic Community (EAEC) Region on the daily stock market index closing prices from January 1999 to March 2015. The findings suggests varying degrees of integration among the sample countries with the Asian benchmark. The study clearly finds that high level of integration exist among non ASEAN but EAEC members (China, Japan, South Korea, Australia, India and New Zealand) compared to ASEAN-5 (Indonesia, Malaysia, Philippines, Singapore and Thailand) members. They identifyfiscal position, stock market performance, external position, governance and trade linkages as the key drivers of financial integration in the region. [37] examines the dynamic nature of equity market integration for the South Asian countries from January 2004 to March 2015 using Copula GARCH and Diebold and Yilmaz methods. They find very little or no integration among these markets.

In sum, the existing literature provides a comprehensive body of knowledge on Asian market integration. However, most of the studies have not covered wide range of Asian markets and instead focused on sub set of markets. Further, existing research has not touched upon more recent period particularly after the Chinese meltdown of 2015-2016. In the present study we cover twelve major Asian markets using data from January 2000 i.e. after the Asian Crisis period to June 2017 covering both GFC as well as the Chinese meltdown phase. Thus our study period provides an opportunity to examine dynamic stock market linkages in the pre-crisis, GFC and post crisis periods, including the period in and around the Chinese meltdown. The later analysis is relevant given the global and the regional importance of China owing to its economic, trade and investment linkages with its Asian neighbors. The study employs ADCC-GARCH model and supplements the analysis using Diebold and Yilmaz (2012) technique which helps us in discerning the level of openness of the sample of Asian economies as well as identifying countries which dominate and those act like satellite markets in the return and volatility spillover process.

\section{Data}

For the study, we select all big Asian economies having GDP of 2017 on PPP basis higher than US $\$ 500$ billion which resulted into 17 countries. However, two most active Asian Financial markets namely, Hong Kong China and Singapore remain excluded because of relatively smaller size of the economy. Thus to include these two countries we considered economies with minimum US\$400 b. All other countries with lower than $\$ 400$ b GDP values do not have active financial markets, hence are not included. Out of these 19 countries $^{2}$, we have to drop seven frontier economies (Iran, UAE, Saudi Arabia, Bangladesh, Iraq, Vietnam ${ }^{2}$ List of select 19 Asian countries (GDP (PPP) in USD billion given in parenthesis): Chinese Mainland (23159), India (9459), Japan (4932), Indonesia (3028), South Korea (2029), Saudi Arabia (1750), Iran (1459), Thailand (1161), Taiwan China (1127), Pakistan (1061), Philippines (1023), Malaysia (863), United Arab Emirates (667.2), Bangladesh (628.4), Iraq (596.7), Vietnam (594.9), Singapore (487.9), Kazakhstan (460.7), Hong Kong China (449.5). 
and Kazakhstan) because of lack of availability of data. As per 2017 data of GDP, the 12 major Asian nations (US $\$ 24,386.31 \mathrm{~b}$ ), available for study, represent approximately $32.4 \%$ of world GDP (US\$75,278.049 b) and is approximately $90 \%$ of the Asia's total GDP (US\$27,222 b). The key economic and financial indicators for the select economies are given in Exhibit 1.

Amongst these select 12 Asian economies Chinese Mainland, Hong Kong China, Taiwan China, Japan and South Korea belong to East Asia; India and Pakistan to South Asia; and Indonesia, Malaysia, Philippines, Singapore, Thailand to Southeast Asia. Since all twelve countries have highly overlapping trading hours owing to their geographical concentration, hence no adjustment is required with respect to time zones as we are using daily files. Daily closing prices for Morgan Stanley Capital Index (MSCI) are fetched from Bloomberg for the period of $3^{\text {rd }}$ January 2000 to $30^{\text {th }}$ June 2017 for each 12 economies along with that of US market which is used as a proxy for global factor [38] [39]. The reason for starting the study from January 2000 is to avoid any impact of Asian Financial Crisis which was concentrated during 1997-99 (see IMF working paper by [4]. The entire time frame of study is further divided into three phases based on the period of global financial crisis which is mostly reported from $9^{\text {th }}$ Aug 2007 to $18^{\text {th }}$ Oct 2009 [40] [41]. The other two periods are pre-crisis starting from $3^{\text {rd }}$ January 2000 to $8^{\text {th }}$ August 2007 and post-crisis period from $19^{\text {th }}$ Oct 2009 till $30^{\text {th }}$ June 2017. The study further makes special mention of China meltdown during 2015-16 without representing the period separately. The study uses natural logarithm of the daily closing values and then daily returns are computed as the first differences of the log-transformed series.

As per exhibit 1 it is clear that in 2017, GDP (nominal) is highest for China (US\$11.94 tn) and lowest for Pakistan (US\$304.4 bn). China is second largest economy at $15.86 \%$ just next to USA which is $25.72 \%$ of world GDP. Forex reserve of China at USD3.16 th is also highest in the world. Hong Kong China at $314 \%$ and Singapore at $238.4 \%$ are two most open economy of the sample countries as measured by the ratio of sum of exports and imports to the GDP. Size of the market, measured by market capitalization to GDP ratio, ranges from 30\% (Pakistan) to $222.4 \%$ (Singapore) with an extreme outlier Hong Kong China (1266.3\%). Most of the sample countries have more than $100 \%$ of this value indicating their big size of the market or they may be seen as overvalued markets. This value for Chinese market is mere $43.43 \%$ which may be treated as undervalued. The reason for the same may be due to very large size of its GDP as well as because of a large number of Chinese companies are listed on Hong Kong China market. However, across the select countries size of the market has increased in the last year from 2016 to 2017 with only exception of Pakistan where it has decreased marginally. This increase in the size is most prominent in Philippines (63\%) followed by in India (50\%). Number of listed companies representing the width of the market, ranges from 264 (Philippines) to 5615 (India). It is interesting to note that listing in India is even higher than that of USA (4336). Depth of the market, measured by value traded to GDP ratio (2016 data), is extremely 


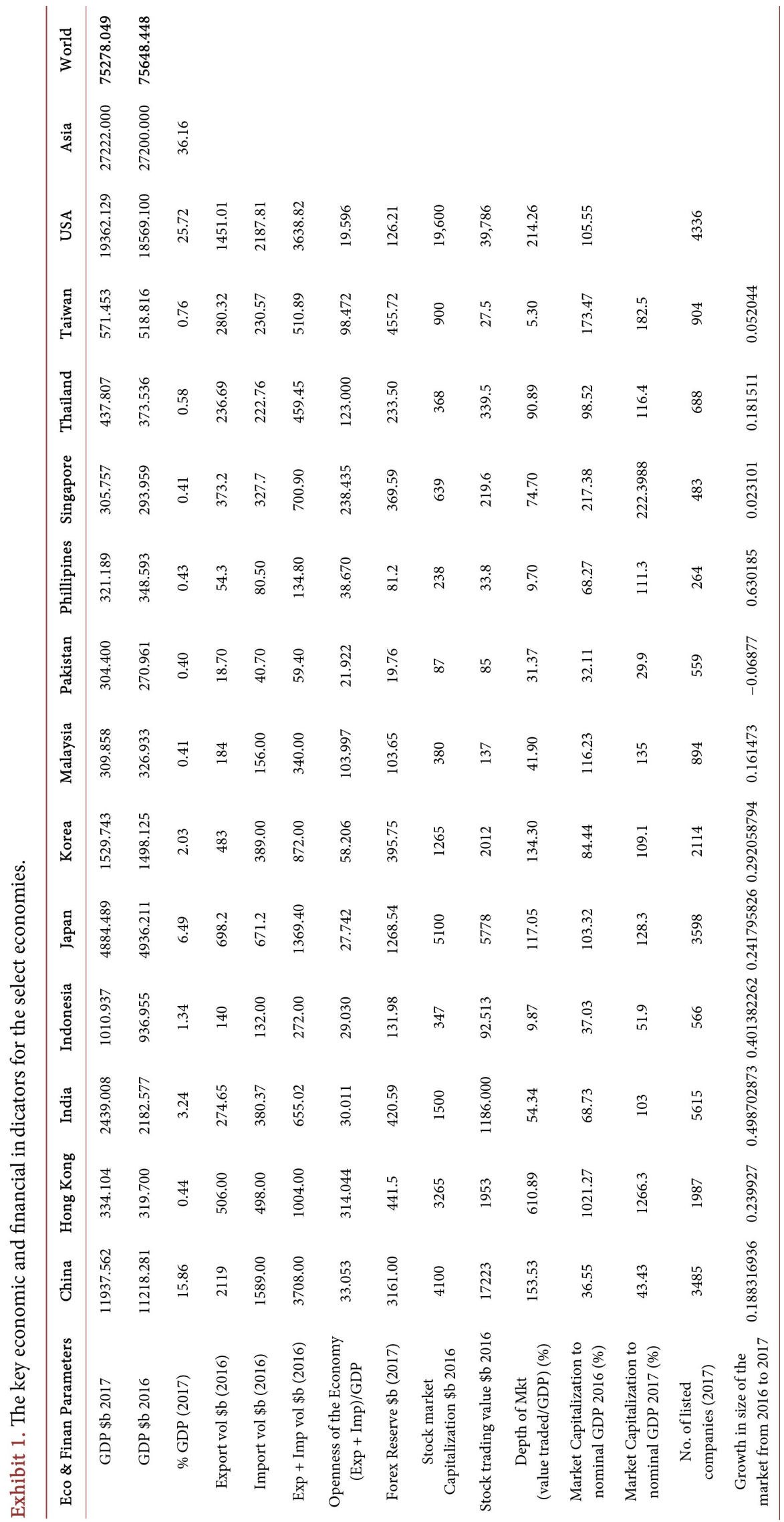


high for Hong Kong China (610.9\%) followed by Chinese Mainland (153.5\%) and Korea (134.3\%). Indonesia, Philippines and Taiwan China have less than $10 \%$ value indicating no depth in these markets.

\section{Methodology}

In this section, the methodologies of constructing different indicators employed to measure the correlations and linkages through return and volatility spillovers are described. We apply Asymmetric Dynamic Conditional Correlation (ADCCGARCH) model proposed by [42] to measure the correlations and [1] Spillover Index for testing the cross market spillovers.

\section{a) Asymmetric Dynamic Conditional Correlation (ADCC)}

ADCC model estimates time-varying correlations by taking into account conditional asymmetries in correlation dynamics which are observed to increase more after the joint negative shock than the joint positive shock.

Asymmetric dynamic conditional correlations are estimated following a two-step procedure. Firstly, univariate volatility for each return series is modelled using Exponential GARCH (EGARCH) process as it accounts for asymmetries in conditional variances of returns and also doesn't impose non-negativity restrictions on GARCH parameters [43]. The mean equation indicated as an AR(1) process in which the global impact is filtered by lagged US returns. We specify variance equation as an EGARCH $(1,1)^{3}$ process in terms of conditional variance of returns $\left(h_{i, t}\right)$.

Error terms are assumed to follow student's $t$ distribution to capture skewed and fat tail characteristic of innovations [44] and make the estimations robust to deviations from normality [45] [46].

Conditional covariance matrix $H_{t}$ is decomposed as $H_{t}=D_{t} R_{t} D_{t}$, where $D_{t}=\operatorname{diag}\left\{\sqrt{h}_{i, t}\right\}$ is $n \times n$ diagonal matrix of time-varying standard deviations for the returns that are extracted from EGARCH $(1,1)$ process and $R_{t}=\left\{\rho_{i j}\right\}_{t}$ is $n \times n$ time-varying correlation matrix.

After obtaining the estimates of $h_{i, t}$ from EGARCH $(1,1)$ model, standardized residuals i.e. returns transformed by their estimated standard deviation $\left(\left(\varepsilon_{i, t}=r_{i, t} / \sqrt{h_{i, t}}\right)\right.$ are used to estimate dynamic conditional correlation parameters in the second step.

The asymmetric dynamic correlation structure of [42] is given as:

$$
Q_{t}=\left(\bar{Q}-a^{2} \bar{Q}-b^{2} \bar{Q}-g^{2} \bar{N}\right)+a^{2}\left(\varepsilon_{t-1} \varepsilon_{t-1}^{\prime}\right)+b^{2} Q_{t-1}+g^{2}\left(\eta_{t-1} \eta_{t-1}^{\prime}\right),
$$

where $Q_{t}$ is positive definite if the matrix in parentheses is positive semi-definite, $\bar{Q}=E\left(\varepsilon_{t} \varepsilon_{t}^{\prime}\right)$ is $n \times n$ is unconditional correlation matrix of standardized residuals, $\quad \bar{N}=E\left(\eta_{t} \eta_{t}^{\prime}\right)$ and $g$ is the asymmetric term which captures the period of joint negative shock. For $Q_{t}$ to be positive definite, the matrix in parentheses should positive semi-definite.

The dynamic correlation matrix is written as:

$$
P_{t}=Q_{t}^{*-1} Q_{t} Q_{t}^{*-1},
$$

${ }^{3} \mathrm{EGARCH}(1,1)$ is a preferred model in interest of parsimony of parameters [53]. 
where $Q_{t}^{*}=\left[\sqrt{q_{i i t}}\right]$ is a diagonal matrix with the square root of the $i^{\text {th }}$ diagonal elements of $Q_{t}$ on its diagonal entries.

ADCC model has advantages over other multivariate GARCH models. ADCC model parametrizes conditional correlations, while other specifications like VEC and BEKK require indirect computations of conditional correlations as they parametrize conditional co-variances. Constant Conditional Correlation (CCC) model introduced by [47] assumes correlations to be constant which is neither realistic nor empirically justified and its estimation involves solving a high dimensional optimization problem. Dynamic Conditional Correlation (DCC) model proposed by [48] relaxes the assumption of constant correlation and provides flexibility by reducing the number of parameters to estimate [49]. However, ADCC model is preferred as it nests DCC model and incorporate asymmetries in conditional correlations.

\section{b) Diebold and Yilmaz (2012) Spillover Index}

Spillover index methodology proposed by [1], based on vector autoregressive (VAR) framework, allows us to examine within and cross market spillovers. It quantifies the contribution of shocks to and from each variable in terms of each variable's forecast error variance through variance decomposition analysis, and therefore provides the magnitude and direction of spillovers. Diebold and Yilmaz (2012) uses generalized VAR framework of [50] [51] which yields forecast-error variance decompositions that are invariant to the ordering of the variables.

The $N$ variable VAR of $p^{\text {th }}$ order can be written as: $y_{t}=\sum_{i=1}^{p} \phi_{i} y_{t-i}+\varepsilon_{t}$, where $y_{t}=\left(y_{1 t}, \cdots, y_{N t}\right)$ is a vector of $N$ endogenous variables, $\theta_{i}$ is $N \times N$ parameter matrix and $\varepsilon_{t} \sim(0, \Sigma)$ is a vector of innovations. Its moving average representation can be written as $y_{t}=\sum_{i=1}^{\infty} A_{i} \varepsilon_{t-i}$, where $A_{i}=\sum \phi_{j} A_{i-j}$ and $j=1, \cdots, p$.

The $H$-step ahead forecast error variance decomposition of $I^{\text {th }}$ variable which can be attributed to shocks for $f^{\text {th }}$ variableis given as:

$$
\theta_{i \leftarrow j}^{g}(H)=\frac{\sigma_{i i}^{-1} \sum_{h=0}^{H=-1}\left(e_{i}^{\prime} A_{h} \sum e_{j}\right)^{2}}{\sum_{h=0}^{H=-1}\left(e_{i}^{\prime} A_{h} \sum A_{h}^{\prime} e_{j}\right)} \text {, for } i, j=1, \cdots, N
$$

where $\Sigma$ is the estimated variance matrix for the error term of VAR, $\sigma_{i j}$ is the standard deviation of the error term for the $i^{\text {th }}$ equation and $e_{i}$ is the selection vector with one for the $i^{\text {th }}$ element and zero otherwise. Each forecast error variance decomposition is normalized by the row sum as:

$$
\theta_{i \leftarrow j}^{g}(H)=\frac{\theta_{i \leftarrow j}^{g}(H)}{\sum_{j=1}^{N} \theta_{i \leftarrow j}^{g}(H)}
$$

Total Connectedness is calculated as the summation of cross-variance shares, which are the fraction of the $\mathrm{H}$ step ahead error variances in forecasting $y_{i}$ due to shocks to $y_{j}$. The shocks received by vector $i$ from all other vectors $j$ and vice versa is measured through Directional Connectedness whereas Net Connectedness is the difference between the shocks transmitted to and shocks transmitted from all other markets. 


\section{Empirical Results}

The study is based on daily equity returns from 12 Asian countries having total 4266 observations for each market. The index returns for the sample countries have been analyzed for the total period and three sub periods. The descriptive statistics are provided in Table 1 panel a tod.

For the total period, the annualized mean return ${ }^{4}$ is highest for Korea (8\%) followed by Indonesia (7.75\%) and India (7.50\%) while the lowest positive return is for Taiwan China (0.75\%). Japan has annualized average return of $-0.25 \%$. Performing sub period analysis, it is interesting to observe that Pakistan provided highest pre-crisis return (17.225\%) which turned into lowest return $(-29.675 \%)$ during the crisis period. In the crisis time Indonesia was the best performer and had given an annualized return of $14.925 \%$. Philippines outperformed other sample markets in post crisis period with an annual return of $11.10 \%$. During this period China had the lowest return $(0.212 \%)$.

Volatility, measured by standard deviation, is relatively very high during crisis period compared to pre and post crisis periods. Korea exhibits highest volatility throughout the study period. In general, the volatility increased 1.5 to 2 times from pre-crisis to crisis period but went down dramatically during post crisis period, even lower than the figures for the pre-crisis period.

For the total period, the return distributions of these equity markets are negatively skewed with the exception of China and Philippines and further all sample series are Leptokurtic with the value as high as 20.47 for Philippines. The Jarque-Bera Test indicates that mean returns for sample indices are not normally distributed. The Ljung-Box test confirms that mean returns of sample equity markets are not independently distributed. The ARCH-LM test confirms clustering effect in the volatility of sample series. Thus, Asymmetric Dynamic Conditional Correlations (ADCC-GARCH) model is used to find the associations between Sample Equity Markets.

Table 2 provides ADCC results. It can be clearly seen that Singapore exhibits highest correlation (0.382) on an average with all other sample equity markets followed by Chinese Mainland and Hong Kong China. Pakistan's equity market exhibits the least association with an average correlation of 0.061. Surprisingly, Japan despite being an advanced economy, seems to be poorly correlated with other Asian markets with an average value of 0.223. Pairwise highest correlation is exhibited by Chinese Mainland and Hong Kong China (0.752) which is not surprising, followed by Hong Kong China-Singapore (0.537) and Chinese Mainland-Singapore (0.504). Japan exhibits highest correlation with Korea (0.366) which is again not surprising given the close economic ties between the two countries $^{5}$. The Indian equity market has strongest correlation with Singapore (0.387) followed by China (0.381).

${ }^{4}$ Annualized mean return is calculated by multiplying the daily mean return with 250 and then converted into percentage point.

${ }^{5}$ This may also be due to the geopolitical issues relating to uncertainty posed by North Korea which makes the equity market of these two countries move with each other. 
Table 1. (a) Descriptive statistics of sample equity return series (entire study period i.e. $3^{\text {rd }}$ Jan 2000 to $30^{\text {th }}$ June 2017); (b) Descriptive statistics of sample equity return series (Pre-crisis period i.e. $3^{\text {rd }}$ Jan 2000 to $8^{\text {th }}$ Aug 2007); (c) Descriptive statistics of sample equity return series: crisis period (9 August 2007 to 18 October 2009); (d) Descriptive statistics of sample equity return series: post crisis period (19 October 2009 to 30 June 2017).

(a)

\begin{tabular}{|c|c|c|c|c|c|c|c|c|c|c|}
\hline & Mean & Std. Dev. & $\operatorname{Max}$ & Min & Skew & Kurt & $\mathrm{JB}$ & LB & ARCH LM & Obsv \\
\hline CHI & 0.00015 & 0.01780 & 0.14044 & -0.12836 & 0.09 & 8.68 & $\begin{array}{c}5744.50^{* * *} \\
{[0.00]}\end{array}$ & $\begin{array}{c}32.92^{* * *} \\
{[0.00]}\end{array}$ & $\begin{array}{c}266.88^{* * *} \\
{[0.00]}\end{array}$ & 4266 \\
\hline HKG & 0.00011 & 0.01322 & 0.10449 & -0.12567 & -0.16 & 9.62 & $\begin{array}{c}7804.37^{* * *} \\
{[0.00]}\end{array}$ & $\begin{array}{l}10.18^{*} \\
{[0.60]}\end{array}$ & $\begin{array}{c}473.09^{* * *} \\
{[0.00]}\end{array}$ & 4266 \\
\hline IND & 0.00030 & 0.01692 & 0.19486 & -0.12041 & -0.06 & 10.91 & $\begin{array}{c}11122.34^{* * *} \\
{[0.00]}\end{array}$ & $\begin{array}{c}79.18^{* * *} \\
{[0.00]}\end{array}$ & $\begin{array}{c}142.11^{* * *} \\
{[0.00]}\end{array}$ & 4266 \\
\hline INDON & 0.00031 & 0.01942 & 0.15042 & -0.19947 & -0.45 & 10.58 & $\begin{array}{c}10349.35^{* * *} \\
{[0.00]}\end{array}$ & $\begin{array}{c}56.64^{* * *} \\
{[0.00]}\end{array}$ & $\begin{array}{c}81.46^{* * *} \\
{[0.00]}\end{array}$ & 4266 \\
\hline JAP & -0.00001 & 0.01399 & 0.11467 & -0.09513 & -0.12 & 7.06 & $\begin{array}{c}2945.30^{* * *} \\
{[0.00]}\end{array}$ & $\begin{array}{c}47.32^{* * *} \\
{[0.000]}\end{array}$ & $\begin{array}{c}187.04^{* * *} \\
{[0.00]}\end{array}$ & 4266 \\
\hline KOR & 0.00032 & 0.01982 & 0.24987 & -0.20672 & -0.15 & 15.38 & $\begin{array}{c}27254.07^{* * *} \\
{[0.00]}\end{array}$ & $\begin{array}{c}25.10^{* * *} \\
{[0.01]}\end{array}$ & $\begin{array}{c}39.33^{* * *} \\
{[0.00]}\end{array}$ & 4266 \\
\hline MLY & 0.00021 & 0.01009 & 0.05784 & -0.11279 & -0.35 & 10.35 & $\begin{array}{c}9680.37^{* * *} \\
{[0.00]}\end{array}$ & $\begin{array}{c}96.88^{* * *} \\
{[0.00]}\end{array}$ & $\begin{array}{c}50.95^{* * *} \\
{[0.00]}\end{array}$ & 4266 \\
\hline PAK & 0.00027 & 0.01594 & 0.09491 & -0.12858 & -0.27 & 7.64 & $\begin{array}{c}3885.31^{* * *} \\
{[0.00]}\end{array}$ & $\begin{array}{c}92.59^{* * *} \\
{[0.00]}\end{array}$ & $\begin{array}{c}391.45^{* * *} \\
{[0.00]}\end{array}$ & 4266 \\
\hline PHLP & 0.00019 & 0.01533 & 0.21972 & -0.14494 & 0.62 & 20.47 & $\begin{array}{c}54499.71^{* * *} \\
{[0.00]}\end{array}$ & $\begin{array}{c}81.91^{* * *} \\
{[0.00]}\end{array}$ & $\begin{array}{c}57.68^{* * *} \\
{[0.00]}\end{array}$ & 4266 \\
\hline SNG & 0.00009 & 0.01310 & 0.08563 & -0.09809 & -0.19 & 8.05 & $\begin{array}{c}4556.39^{* * *} \\
{[0.00]}\end{array}$ & $\begin{array}{c}38.76^{* * *} \\
{[0.00]}\end{array}$ & $\begin{array}{c}168.59^{* * *} \\
{[0.00]}\end{array}$ & 4266 \\
\hline THAI & 0.00030 & 0.01671 & 0.10521 & -0.18085 & -0.50 & 10.90 & $\begin{array}{c}11279.99^{* * *} \\
{[0.00]}\end{array}$ & $\begin{array}{c}41.52^{\star * *} \\
{[0.00]}\end{array}$ & $\begin{array}{c}359.96^{* * *} \\
{[0.00]}\end{array}$ & 4266 \\
\hline TWN & 0.00003 & 0.01551 & 0.08232 & -0.10941 & -0.06 & 6.13 & $\begin{array}{c}1747.11^{* * *} \\
{[0.00]}\end{array}$ & $\begin{array}{c}38.35^{* * *} \\
{[0.00]}\end{array}$ & $\begin{array}{c}85.55^{* * *} \\
{[0.00]}\end{array}$ & 4266 \\
\hline US & 0.00010 & 0.01227 & 0.11042 & -0.09514 & -0.17 & 11.59 & $\begin{array}{c}13145.52^{* * *} \\
{[0.00]}\end{array}$ & $\begin{array}{c}61.16^{* * *} \\
{[0.00]}\end{array}$ & $\begin{array}{c}208.45^{* * *} \\
{[0.00]}\end{array}$ & 4266 \\
\hline
\end{tabular}

(b)

\begin{tabular}{|c|c|c|c|c|c|c|c|c|}
\hline & Mean & Std. Dev. & Maximum & Minimum & Skewness & Kurtosis & Jarque-Bera & Obsv \\
\hline $\mathrm{CHI}$ & 0.000262 & 0.017235 & 0.110218 & -0.07479 & 0.002763 & 5.82652 & $\begin{array}{c}621.8298^{* * *} \\
{[0.00]}\end{array}$ & 1868 \\
\hline HKG & $8.91 \mathrm{E}-05$ & 0.012322 & 0.05836 & -0.09026 & -0.25397 & 6.316058 & $\begin{array}{c}875.955^{* * *} \\
{[0.00]}\end{array}$ & 1868 \\
\hline IND & 0.000517 & 0.016151 & 0.082633 & -0.11951 & -0.67896 & 7.138305 & $\begin{array}{c}1476.459^{* * *} \\
{[0.00]}\end{array}$ & 1868 \\
\hline INDON & 0.00031 & 0.020173 & 0.106192 & -0.19947 & -0.72013 & 10.57948 & $\begin{array}{c}4632.863^{* * *} \\
{[0.00]}\end{array}$ & 1868 \\
\hline JAP & $1.20 \mathrm{E}-05$ & 0.013319 & 0.067223 & -0.06608 & -0.04803 & 4.540449 & $\begin{array}{c}185.4155^{* * *} \\
{[0.00]}\end{array}$ & 1868 \\
\hline KOR & 0.000405 & 0.020552 & 0.091756 & -0.12157 & -0.21497 & 5.917358 & $\begin{array}{c}676.8246^{* * *} \\
{[0.00]}\end{array}$ & 1868 \\
\hline MLY & 0.000281 & 0.009769 & 0.04961 & -0.06973 & -0.35115 & 8.178831 & $\begin{array}{c}2125.902^{* * *} \\
{[0.00]}\end{array}$ & 1868 \\
\hline PAK & 0.000689 & 0.017969 & 0.087765 & -0.08463 & -0.14717 & 5.97568 & $\begin{array}{c}695.9315^{* * *} \\
{[0.00]}\end{array}$ & 1868 \\
\hline PHLP & 0.000107 & 0.015633 & 0.219717 & -0.08748 & 2.033579 & 31.82845 & $\begin{array}{c}65973.2^{* * *} \\
{[0.00]}\end{array}$ & 1868 \\
\hline SNG & 0.000184 & 0.012165 & 0.056969 & -0.07824 & -0.30522 & 5.852458 & $\begin{array}{c}662.2952^{* * *} \\
{[0.00]}\end{array}$ & 1868 \\
\hline THAI & 0.000284 & 0.017796 & 0.105206 & -0.18085 & -0.54512 & 11.00469 & $\begin{array}{c}5079.69^{* * *} \\
{[0.00]}\end{array}$ & 1868 \\
\hline TWN & $-6.96 \mathrm{E}-05$ & 0.017244 & 0.079286 & -0.10941 & -0.00868 & 5.691144 & $\begin{array}{c}563.7123^{* * *} \\
{[0.00]}\end{array}$ & 1868 \\
\hline US & $-3.74 \mathrm{E}-06$ & 0.011034 & 0.056113 & -0.06161 & 0.122831 & 5.787532 & $\begin{array}{c}609.4883^{* * *} \\
{[0.00]}\end{array}$ & 1868 \\
\hline
\end{tabular}


(c)

\begin{tabular}{|c|c|c|c|c|c|c|c|c|c|}
\hline & Mean & Std. Dev. & Maximum & Minimum & Skewness & Kurtosis & Jarque-Bera & Probability & Obsv \\
\hline $\mathrm{CHI}$ & 0.000215 & 0.030111 & 0.14044 & -0.12836 & 0.169502 & 5.59606 & 152.7971 & 0 & 535 \\
\hline HKG & -0.00011 & 0.022409 & 0.104485 & -0.12567 & -0.00249 & 6.400022 & 257.6955 & 0 & 535 \\
\hline IND & 0.000442 & 0.028205 & 0.194864 & -0.12041 & 0.380886 & 7.816851 & 530.1482 & 0 & 535 \\
\hline INDON & 0.000597 & 0.028044 & 0.15042 & -0.14576 & -0.13154 & 7.345247 & 422.4357 & 0 & 535 \\
\hline KOR & -0.00013 & 0.031211 & 0.249866 & -0.20672 & 0.002321 & 15.33469 & 3391.555 & 0 & 535 \\
\hline MLY & 0.000204 & 0.014495 & 0.055464 & -0.11279 & -0.69273 & 10.35308 & 1248.05 & 0 & 535 \\
\hline PAK & -0.00119 & 0.022296 & 0.09491 & -0.12858 & -0.36438 & 5.986947 & 210.7217 & 0 & 535 \\
\hline PHLP & -0.00037 & 0.021819 & 0.093268 & -0.14494 & -0.49431 & 7.9047 & 558.0373 & 0 & 535 \\
\hline THAI & $3.34 \mathrm{E}-05$ & 0.022661 & 0.097336 & -0.14575 & -0.6518 & 8.679858 & 757.0279 & 0 & 535 \\
\hline TWN & -0.00013 & 0.020831 & 0.082315 & -0.06475 & -0.02602 & 4.163311 & 30.22751 & 0 & 535 \\
\hline US & -0.00057 & 0.02136 & 0.110419 & -0.09514 & -0.09501 & 7.582771 & 468.9698 & 0 & 535 \\
\hline
\end{tabular}

(d)

\begin{tabular}{|c|c|c|c|c|c|c|c|c|c|}
\hline & Mean & Std. Dev. & Maximum & Minimum & Skewness & Kurtosis & Jarque-Bera & Probability & Obsv \\
\hline $\mathrm{CHI}$ & $8.49 \mathrm{E}-06$ & 0.012967 & 0.065463 & -0.06606 & -0.13904 & 5.83979 & 632.0022 & 0 & 1863 \\
\hline HKG & 0.000198 & 0.010194 & 0.058038 & -0.05313 & -0.27804 & 5.973645 & 710.4071 & 0 & 1863 \\
\hline IND & $4.59 \mathrm{E}-05$ & 0.01289 & 0.058229 & -0.07479 & -0.18627 & 5.309838 & 424.9303 & 0 & 1863 \\
\hline INDON & 0.000226 & 0.015186 & 0.077309 & -0.09799 & -0.272 & 7.381796 & 1513.383 & 0 & 1863 \\
\hline JAP & 0.000125 & 0.012167 & 0.071307 & -0.08555 & -0.35883 & 6.967249 & 1261.724 & 0 & 1863 \\
\hline KOR & 0.000354 & 0.014033 & 0.069265 & -0.08055 & -0.22601 & 5.490967 & 497.5175 & 0 & 1863 \\
\hline MLY & 0.000149 & 0.00879 & 0.057838 & -0.04451 & 0.17281 & 6.74813 & 1099.786 & 0 & 1863 \\
\hline PAK & 0.00026 & 0.010728 & 0.045433 & -0.06447 & -0.23899 & 5.703849 & 585.2354 & 0 & 1863 \\
\hline PHLP & 0.000442 & 0.012511 & 0.064119 & -0.07937 & -0.52927 & 6.94788 & 1296.824 & 0 & 1863 \\
\hline SNG & $6.41 \mathrm{E}-05$ & 0.010136 & 0.051257 & -0.04969 & -0.21465 & 5.667993 & 566.856 & 0 & 1863 \\
\hline THAI & 0.000393 & 0.013214 & 0.070689 & -0.06229 & 0.005954 & 5.97595 & 687.4797 & 0 & 1863 \\
\hline TWN & 0.000187 & 0.011318 & 0.051399 & -0.05667 & -0.22111 & 5.077962 & 350.359 & 0 & 1863 \\
\hline US & 0.000401 & 0.009565 & 0.046877 & -0.0696 & -0.45498 & 7.491264 & 1630.084 & 0 & 1863 \\
\hline
\end{tabular}

Notes: (a) CHI, HKG, IND, INDON, JAP, KOR, MLY, PAK, PHLP, SNG, THAI, TWN AND US DENOTE Chinese Mainland, Hong Kong China, India, Indonesia, Japan, Korea, Malaysia, Pakistan, Philippines, Singapore, Thailand, Taiwan China and United States, respectively. Std. Dev., Max, Min, Skew and Kurt denote Standard Deviation, Maximum, Minimum, Skewness and Kurtosis of the return series. (b) JB denotes Jarque-Bera test for the null hypothesis of normal distribution. (c) LB denotes Ljung-Box Q-statistic reported at $12^{\text {th }}$ lag and ARCH LM denotes ARCH Lagrange Multiplier test of conditional hete-

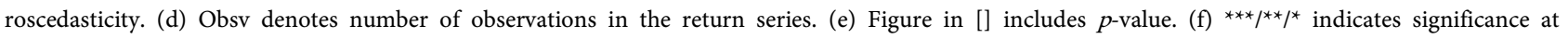
$0.01 / 0.05 / 0.10$ level.

The graphical presentations of ADCC (see Figure 1) provide dynamic estimates of cross conditional correlations. Such an analysis helps us in understanding how the conditional correlations have varied over time and particularly over the sub-periods. It is observed that Chinese Mainland, Hong Kong China, Korea, India, Thailand and Indonesia have low correlations in pre-crisis period which increased during crisis period and remained high (0.6) in the initial phase of 
Table 2. Asymmetric conditional correlations among sample equity markets.

\begin{tabular}{|c|c|c|c|c|c|c|c|c|c|c|c|c|c|}
\hline & $\mathrm{CHI}$ & HKG & IND & INDON & JAP & KOR & MLY & PAK & PHLP & SNG & THAI & TWN & $\begin{array}{c}\text { Average } \\
\text { Correlations }\end{array}$ \\
\hline $\mathrm{CHI}$ & 1.000 & & & & & & & & & & & & 0.378 \\
\hline HKG & 0.752 & 1.000 & & & & & & & & & & & 0.372 \\
\hline IND & 0.381 & 0.363 & 1.000 & & & & & & & & & & 0.280 \\
\hline INDON & 0.347 & 0.324 & 0.305 & 1.000 & & & & & & & & & 0.295 \\
\hline JAP & 0.285 & 0.283 & 0.145 & 0.165 & 1.000 & & & & & & & & 0.223 \\
\hline KOR & 0.466 & 0.475 & 0.329 & 0.329 & 0.366 & 1.000 & & & & & & & 0.365 \\
\hline MLY & 0.358 & 0.342 & 0.293 & 0.382 & 0.204 & 0.373 & 1.000 & & & & & & 0.316 \\
\hline PAK & 0.039 & 0.028 & 0.073 & 0.070 & 0.032 & 0.068 & 0.090 & 1.000 & & & & & 0.061 \\
\hline PHLP & 0.244 & 0.226 & 0.213 & 0.295 & 0.170 & 0.276 & 0.302 & 0.055 & 1.000 & & & & 0.230 \\
\hline SNG & 0.504 & 0.537 & 0.387 & 0.394 & 0.321 & 0.476 & 0.442 & 0.076 & 0.258 & 1.000 & & & 0.382 \\
\hline THAI & 0.365 & 0.350 & 0.303 & 0.336 & 0.193 & 0.324 & 0.349 & 0.068 & 0.244 & 0.396 & 1.000 & & 0.292 \\
\hline TWN & 0.414 & 0.409 & 0.291 & 0.302 & 0.288 & 0.533 & 0.339 & 0.067 & 0.251 & 0.416 & 0.288 & 1.000 & 0.327 \\
\hline
\end{tabular}

Note: The table presents pairwise asymmetric correlations of the sample equity markets, averaged overtime. The last column of the table depicts conditional correlations of each Asian market with rest of the sample markets on an average.

\section{Average Conditional Correlations}

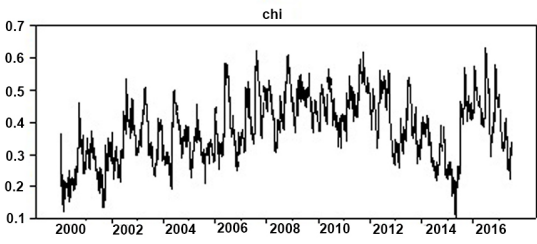

hkg
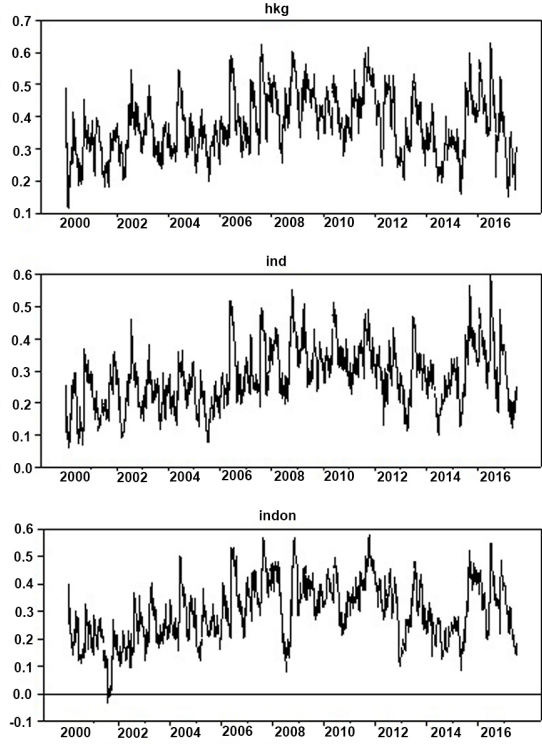

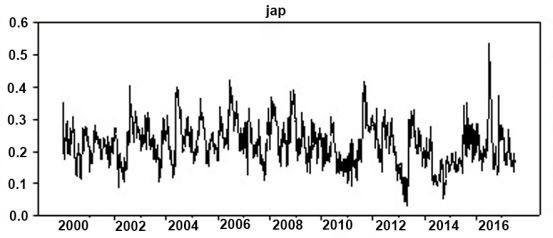

kor
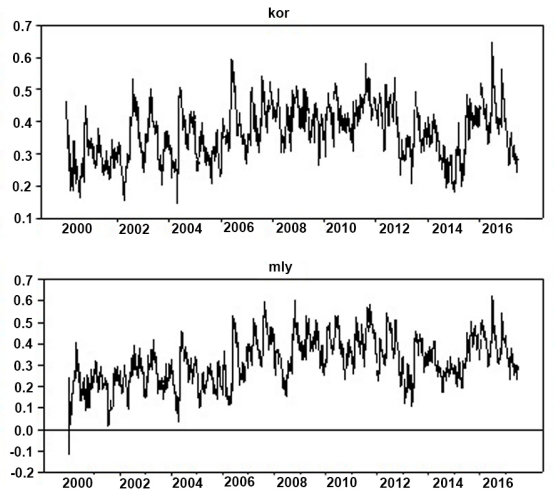

pak

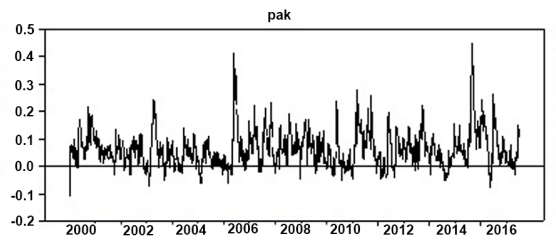

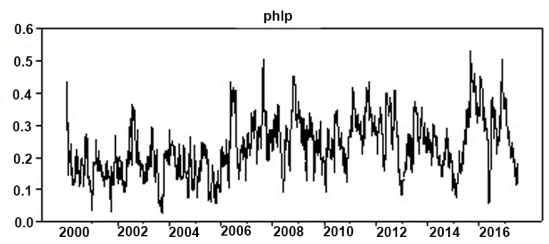
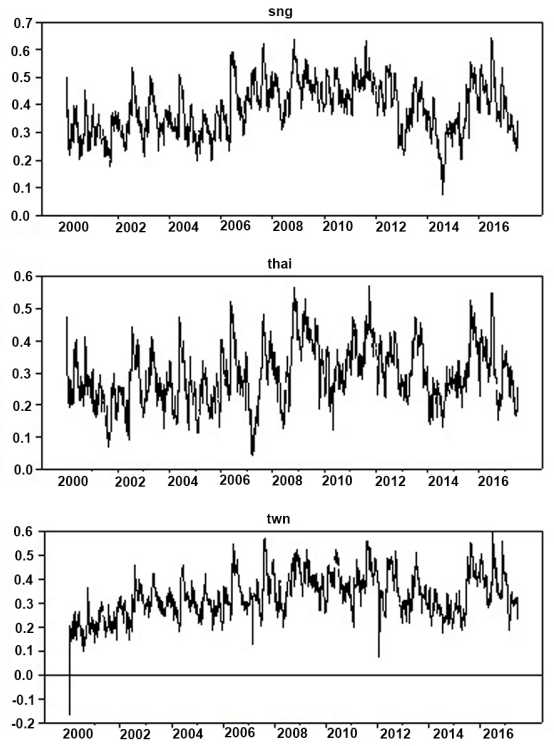

Figure 1. Dynamic conditional correlations of the Asian markets. Notes: (a) The figure depicts dynamic conditional correlations of each Asian market with rest of the sample markets on an average, computed from the ADCC model; (b) chi, hkg, ind, indon, jap, kor, mly, pak, phlp, sng, thai and twn denote Chinese Mainland, Hong Kong China, India, Indonesia, Japan, Korea, Malaysia, Pakistan, Philippines, Singapore, Thailand and Tawan, respectively. 
post crisis before coming down to a figure as low as 0.1 in 2015. In 2016, correlations again rose to 0.6 but again decreased to 0.2 during the last period of the study. The results for 2016 are interesting as this period coincides with Chinese meltdown. It may be noted that China's growth rate has moved to a lower trajectory since 2016 and there was a bust in stock market and real estate pricing bubbles in the latter half of this year. Increased associations during GFC as well as Chinese meltdown periods followed by steep decline can be characterized as market contagion and decoupling behavior. GFC impacted the entire world including the Asian markets while the later shock particularly impacted the Asian markets owing to their regional proximity and strong economic and trade relation with China. Singapore has shown higher association throughout the study period which further got strengthen during the GFC period again implying a contagion effect. For Singapore, weakening of the correlation in 2014 (with a value of 0.1 ) and followed by a recovery (with a correlation of 0.6) in 2016 is clearly visible from the graph. Interestingly, Malaysia and Taiwan China started with negative correlation $(-0.1)$ but maintained a positive correlation thereafter with higher association during crisis and post crisis periods. Philippines shows slightly higher association during post crisis period compared to pre-crisis period. Japan on the other hand, has shown an average association ranging between 0.12 to 0.40 throughout the study period with the exception of very low value of 0.02 during 2013 and a relatively high value of 0.5 in 2016. Pakistan exhibits very low correlation (between -0.1 to +0.2 ) with two distinct positive deviations in 2006 and 2015 with a value of 0.4 .

Table 3 presents return spillovers among the Asian Markets obtained under Diebold-Yilmaz framework in the matrix form. The diagonal elements of the matrix represent within market spillovers and off-diagonal elements represent cross-market spillovers. From the matrix it is clear that Hong Kong China has highest return spillover from other countries $(71.10 \%)$ followed by Singapore (70.80\%) and Chinese Mainland (70.20\%). India's return spillover from others is (57.10\%). Excluding Pakistan (8.90\%) as an outlier in terms of return spillover contribution from others, Japan has lowest value of 51.20\%. Most contributing economy to others within sample equity markets in terms of return spillover is Singapore (97.20\%) followed by Hong Kong China (84.10\%). Contribution of Pakistan is insignificant. Japan and Philippines equity markets also have low contributions to other markets in terms of return spillovers. India contributes $54.50 \%$ to other equity markets. Gross return spillover, an indicator of market openness, measured as the sum of contribution made to others and received from others, indicates that Singapore (168\%) is the most open market followed by Hong Kong China (155.20\%) and Chinese Mainland (150.70\%).

In terms of net return spillover, measured as a difference between contribution to others and contribution from others, Singapore equity market has the highest value (26.40\%) followed by Hong Kong China (13\%) and Chinese Mainland $(10.30 \%)$. Republic of Korea is also a net contributing market with low but positive value of $2.60 \%$. These markets can be termed as dominant markets. 
Table 3. Return spillovers among Asian markets.

\begin{tabular}{cccccccccccccccccc}
\hline & CHI & HKG & IND & INDON & JAP & KOR & MLY & PAK & PHLP & SNG & THAI & TWN & US & $\begin{array}{c}\text { Contri. } \\
\text { From }\end{array}$ & $\begin{array}{c}\text { Gross } \\
\text { Spill }\end{array}$ & $\begin{array}{c}\text { Net } \\
\text { Spill }\end{array}$ \\
\hline CHI & 29.77 & 17.62 & 5.61 & 4.03 & 2.95 & 6.99 & 4.38 & 0.09 & 2.22 & 9.98 & 4.81 & 4.58 & 6.96 & 70.20 & 150.70 & 10.30 \\
HKG & 17.13 & 28.91 & 5.35 & 3.78 & 2.96 & 7.37 & 4.03 & 0.08 & 2.05 & 10.99 & 4.79 & 4.74 & 7.81 & 71.10 & 155.20 & 13.00 \\
IND & 7.65 & 7.54 & 42.93 & 4.66 & 1.10 & 5.38 & 4.14 & 0.46 & 2.23 & 9.59 & 4.94 & 3.69 & 5.71 & 57.10 & 111.60 & -2.60 \\
INDON & 5.74 & 5.70 & 5.19 & 43.26 & 1.50 & 4.72 & 5.92 & 0.25 & 3.87 & 9.18 & 5.93 & 3.98 & 4.77 & 56.70 & 103.60 & -9.80 \\
JAP & 4.91 & 5.21 & 2.82 & 2.04 & 48.84 & 6.87 & 2.21 & 0.09 & 1.58 & 6.76 & 2.80 & 3.90 & 11.97 & 51.20 & 76.50 & -25.90 \\
KOR & 7.70 & 8.48 & 4.69 & 3.56 & 4.67 & 33.00 & 4.43 & 0.18 & 2.23 & 9.38 & 4.49 & 8.99 & 8.17 & 67.00 & 136.60 & 2.60 \\
MLY & 5.95 & 5.82 & 4.51 & 6.12 & 1.63 & 5.51 & 40.18 & 0.42 & 3.52 & 10.02 & 5.27 & 4.58 & 6.47 & 59.80 & 108.50 & -11.10 \\
PAK & 0.46 & 0.53 & 1.39 & 0.66 & 0.16 & 0.95 & 0.92 & 91.07 & 0.34 & 0.88 & 0.75 & 0.67 & 1.22 & 8.90 & 11.40 & -6.40 \\
PHLP & 4.77 & 4.46 & 4.63 & 5.65 & 1.44 & 4.09 & 5.03 & 0.18 & 46.03 & 6.42 & 4.91 & 3.01 & 9.38 & 54.00 & 79.90 & -28.10 \\
SNG & 9.53 & 10.81 & 6.39 & 5.71 & 3.26 & 7.79 & 6.72 & 0.16 & 2.30 & 29.19 & 5.96 & 5.35 & 6.83 & 70.80 & 168.00 & 26.40 \\
THAI & 6.73 & 6.93 & 5.05 & 5.63 & 2.00 & 5.60 & 5.22 & 0.24 & 2.98 & 8.70 & 41.87 & 3.71 & 5.32 & 58.10 & 109.60 & -6.60 \\
TWN & 6.31 & 6.75 & 4.46 & 3.67 & 3.09 & 10.74 & 4.30 & 0.16 & 2.04 & 8.24 & 3.77 & 38.93 & 7.55 & 61.10 & 110.40 & -11.80 \\
US & 3.63 & 4.22 & 4.36 & 1.35 & 0.50 & 3.59 & 1.44 & 0.19 & 0.57 & 7.07 & 3.02 & 2.10 & 67.97 & 32.00 & 114.20 & 50.20 \\
Contri. to & 80.50 & 84.10 & 54.50 & 46.90 & 25.30 & 69.60 & 48.70 & 2.50 & 25.90 & 97.20 & 51.50 & 49.30 & 82.20 & $55.20 \%$ &
\end{tabular}

Notes: (a) The table presents return spillovers among the Asian Markets obtained under Diebold-Yilmaz framework. (b) The diagonal elements of the matrix represent within market spillovers and off-diagonal elements represent cross-market spillovers. (c) The last row of the table, "contri to", represents directional spillovers to other markets from market $i$. The column "contri from", represents directional spillovers from other markets to market $i$. (d) The last two columns of the table, Gross Spill and Net Spill represent Gross Spillovers (Contri. To + Contri. From) and Net Spillovers (Contri. To - Contri. From) of the sample markets. (e) The bottom right corner of the table (bold face) is the total spillover index. (f) All values are measured in percentage units.

Rest of the sample equity markets have net negative contribution ranging from Philippines $(-28.10 \%)$ to India $(-2.60 \%)$. Such markets can be termed as satellite markets.

Table 4 presents volatility spillovers among the Asian Markets obtained under Diebold-Yilmaz framework. The diagonal elements of the matrix represent within market spillovers and off-diagonal elements represent cross-market spillovers. Singapore $(135.40 \%)$ has the highest market spillover to others followed by India $(85.40 \%)$. In receiving volatility spillover from others Hong Kong China $(78.70 \%)$ is at top followed by Chinese Mainland (71.10\%) and Korea (63.50\%). Singapore (60.30\%) and Philippines (60.30\%) are next in receiving the volatility information from other markets, as in the case of return spillover Pakistan is a distinct outlier in both receiving and contributing the volatility based information with $3.40 \%$ and $1.00 \%$ respectively. Japan is a very low contributor to others (13.10\%) whereas it receives $53.70 \%$ volatility information from others. Philippines equity market also has the similar condition as it contributes only $18.30 \%$ to others whereas it receives $60.30 \%$ volatility information from others.

Based on Gross Spillover, Singapore seems to be the most open economy in the region followed by Chinese Mainland and India. In terms of Net volatility spillover, Singapore and India are the only dominant markets with positive values of $75.10 \%$ and $39.70 \%$ respectively. Rest of the countries exhibit negative net spillovers implying that they act regionally as satellite markets in the volatility 
Table 4. Volatility spillovers among Asian markets.

\begin{tabular}{cccccccccccccccccc}
\hline & CHI & HKG & IND & INDO & JAP & KOR & MLY & PAK & PHLP & SNG & THAI & TWN & US & $\begin{array}{c}\text { Contri. } \\
\text { From }\end{array}$ & $\begin{array}{c}\text { Gross } \\
\text { Spill }\end{array}$ & Net Spill \\
\hline CHI & 28.93 & 12.51 & 9.46 & 4.16 & 1.49 & 5.84 & 3.79 & 0.01 & 2.57 & 15.97 & 1.78 & 4.51 & 8.99 & 71.10 & 134.30 & -7.90 \\
HKG & 15.98 & 21.32 & 9.93 & 4.00 & 1.57 & 5.98 & 3.38 & 0.07 & 2.45 & 18.59 & 1.75 & 3.20 & 11.78 & 78.70 & 130.40 & -27.00 \\
IND & 4.78 & 3.58 & $\mathbf{5 4 . 3 3}$ & 2.32 & 1.51 & 3.89 & 3.12 & 0.32 & 1.25 & 15.19 & 1.18 & 2.25 & 6.28 & 45.70 & 131.10 & 39.70 \\
INDON & 4.54 & 5.01 & 8.33 & $\mathbf{4 5 . 3 9}$ & 0.78 & 5.36 & 5.65 & 0.06 & 2.72 & 12.29 & 1.57 & 3.73 & 4.57 & 54.60 & 91.30 & -17.90 \\
JAP & 5.86 & 4.85 & 5.31 & 2.05 & $\mathbf{4 6 . 2 7}$ & 3.85 & 1.77 & 0.01 & 1.66 & 11.65 & 1.25 & 2.88 & 12.57 & 53.70 & 66.80 & -40.60 \\
KOR & 5.42 & 2.33 & 9.08 & 2.06 & 1.48 & 36.48 & 3.14 & 0.09 & 0.08 & 13.84 & 1.02 & 9.22 & 15.77 & 63.50 & 109.50 & -17.50 \\
MLY & 4.52 & 4.24 & 5.05 & 4.34 & 1.43 & 3.23 & 53.38 & 0.06 & 3.99 & 10.08 & 1.31 & 3.89 & 4.47 & 46.60 & 85.10 & -8.10 \\
PAK & 0.03 & 0.13 & 0.62 & 0.46 & 0.31 & 0.17 & 0.16 & 96.57 & 0.04 & 0.10 & 0.11 & 1.26 & 0.03 & 3.40 & 4.40 & -2.40 \\
PHLP & 5.07 & 4.69 & 7.35 & 7.01 & 1.32 & 2.28 & 4.37 & 0.06 & 39.70 & 14.09 & 2.08 & 2.39 & 9.59 & 60.30 & 78.60 & -42.00 \\
SNG & 7.13 & 5.29 & 11.48 & 3.33 & 1.61 & 4.85 & 6.19 & 0.03 & 0.70 & 39.70 & 1.59 & 3.15 & 14.94 & 60.30 & 195.70 & 75.10 \\
THAI & 4.40 & 4.61 & 6.60 & 3.25 & 0.56 & 2.18 & 2.12 & 0.06 & 1.80 & 8.93 & 60.13 & 1.30 & 4.04 & 39.90 & 54.40 & -25.40 \\
TWN & 4.65 & 4.05 & 6.57 & 3.19 & 0.96 & 7.71 & 4.39 & 0.08 & 0.86 & 8.10 & 0.57 & $\mathbf{5 1 . 6 4}$ & 7.25 & 48.40 & 87.70 & -9.10 \\
US & 0.82 & 0.45 & 5.66 & 0.52 & 0.06 & 0.68 & 0.38 & 0.18 & 0.13 & 6.55 & 0.27 & 1.56 & $\mathbf{8 2 . 7 4}$ & 17.30 & 117.60 & 83.00 \\
Contri. & 63.20 & 51.70 & 85.40 & 36.70 & 13.10 & 46.00 & 38.50 & 1.00 & 18.30 & 135.40 & 14.50 & 39.30 & 100.30 & $\mathbf{4 9 . 5 0 \%}$ & \\
To & & & & & & & & & & & & & & \\
\hline
\end{tabular}

Notes: (a) The table presents volatility spillovers among the Asian Markets obtained under Diebold-Yilmaz framework. (b) The diagonal elements of the matrix represent within market spillovers and off-diagonal elements represent cross-market spillovers. (c) The last row of the table, "contri to", represents directional spillovers to other markets from market $i$. The column "contri from", represents directional spillovers from other markets to market $i$. (d) The last two columns of the table, Gross Spill and Net Spill represent Gross Spillovers (Contri. To + Contri. From) and Net Spillovers (Contri. To - Contri. From) of the sample markets. (e) The bottom right corner of the table (bold face) is the total spillover index. (f) All values are measured in percentage units.

linkage process. The dominance of India can be explained by the fact that since 2014 its capital market has received very high FII flows making it favorable destination among global investors for risk hedging purpose.

The time series patterns of total return spillovers (see Figure 2) among the sample Asian markets indicate that it moved from $40 \%$ in the year 2000 to $75 \%$ in 2016 before coming down to $60 \%$ during the last part of the study. Crisis period has comparatively high return spillovers (in the range of $65 \%$ to $75 \%$ ) again implying contagion effect. The net return spillovers (see Figure 3) depict that Chinese Mainland, Hong Kong China, Singapore and Korea have positive return spillovers throughout the study period with an exception of 2015 where all of them have negative values. On the other hand Japan, Philippines and Pakistan exhibit negative return spillovers over the entire study period. Contrary to these patterns India shows negative return spillover in pre and post crisis periods but positive return spillovers during crisis period. Interestingly, except Japan, Philippines and Pakistan every area showed positive net return spillovers during 2016. This may be due to contagion effect of Chinese slowdown ${ }^{6}$.

${ }^{6}$ Chinese stock market burst on June 12, 2015, and sunk again on July 27 and August 24. Additional slumps occurred on January 4 and 7 and June 14, 2016. This was the result of asset bubble burst because market had surged more than $150 \%$ in one year time from June 2014 to June 2015 whereas, GDP growth rate was halved from $14 \%$ in 2007 to $7.4 \%$ in 2014 . 


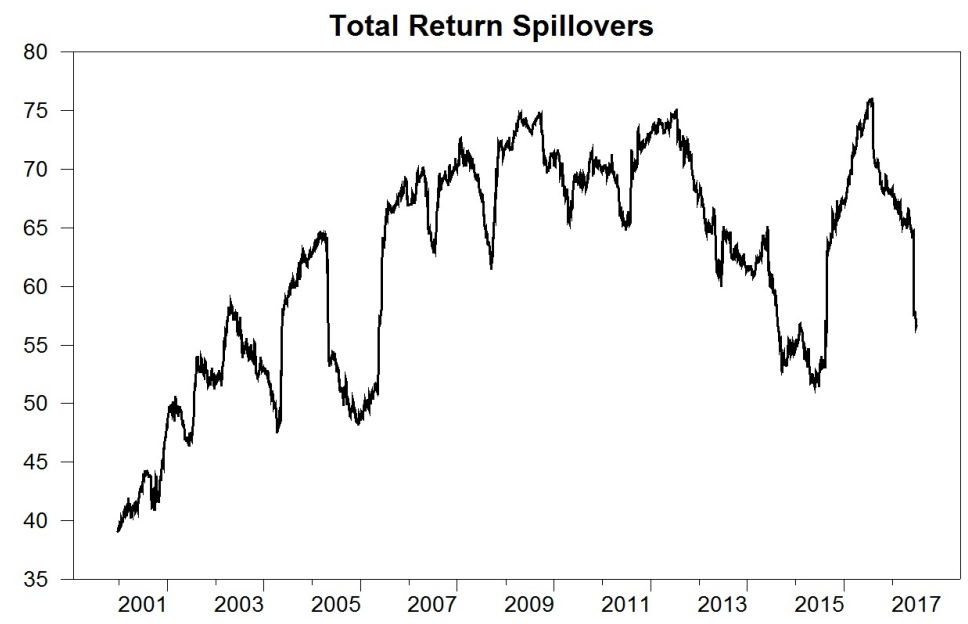

Figure 2. Total return spillovers among the Asian markets. Notes: (a) The figure depicts evolution of the total return spillovers among the sample Asian markets; (b) Dynamic spillover index is obtained using fixed rolling window of 250 days.

\section{Net Return Spillovers}
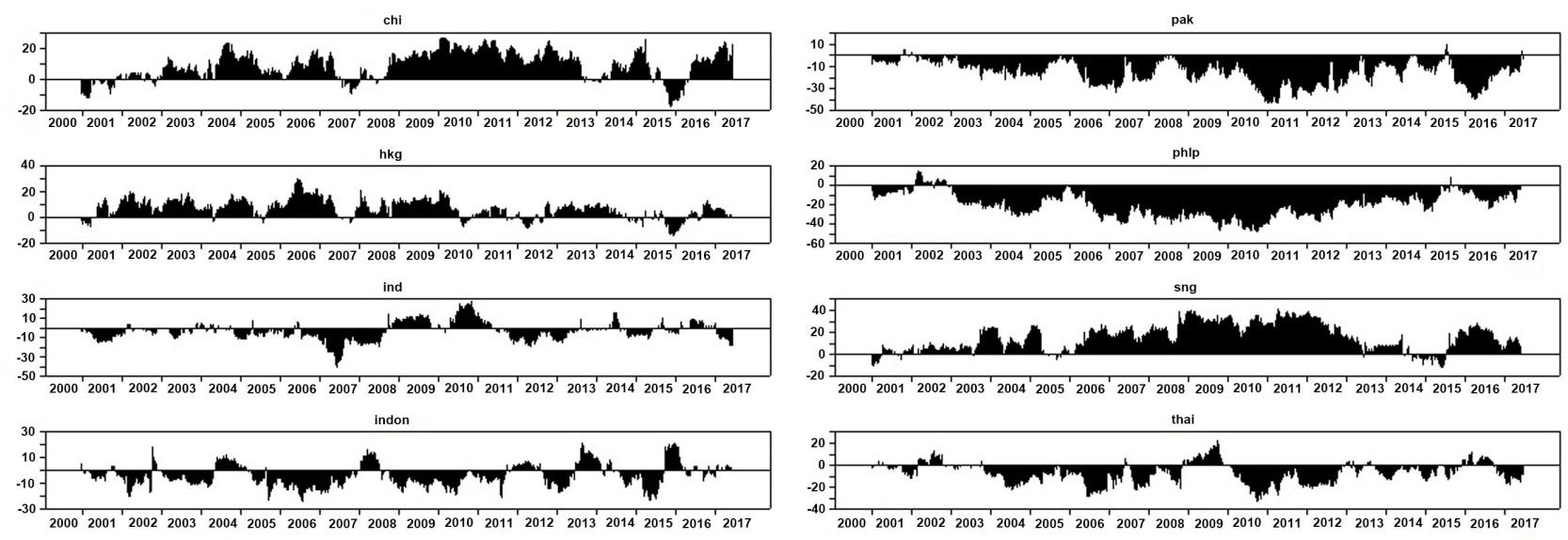

jap
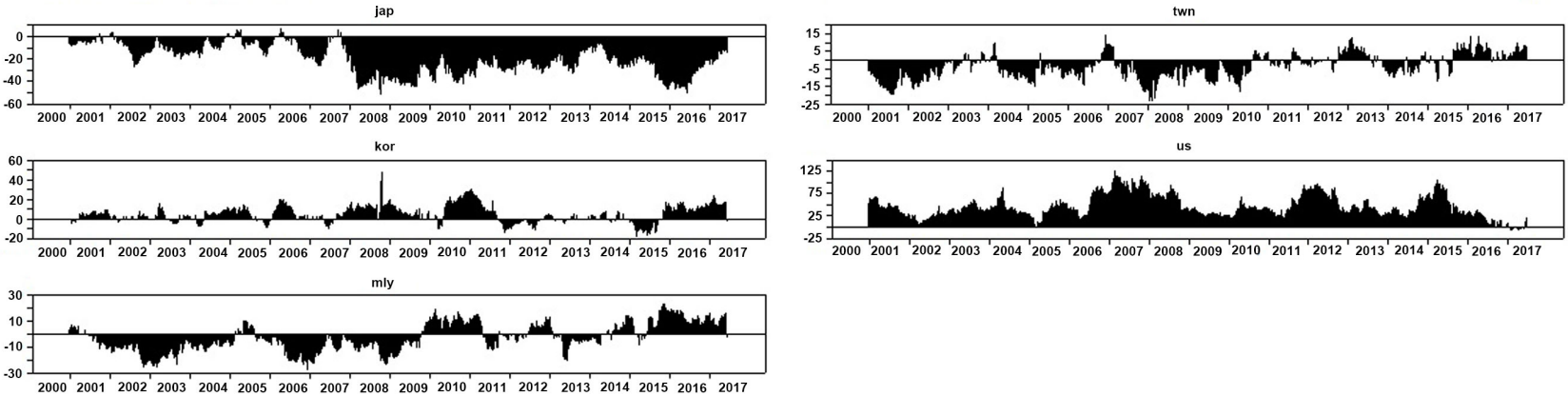

Figure 3. Net return spillovers. Notes: (a) The figure depicts evolution of the net return spillovers of the sample Asian markets; (b) Dynamic spillover index is obtained using fixed rolling window of 250 days.

The time series patterns of total volatility spillovers (see Figure 4) among the sample Asian markets indicate that it doubled from $41 \%$ to $82 \%$ during the period of 2000 to 2016 before coming down to $65 \%$ in the last part of the study. The net volatility spillovers (see Figure 5) depict no clear pattern for any 


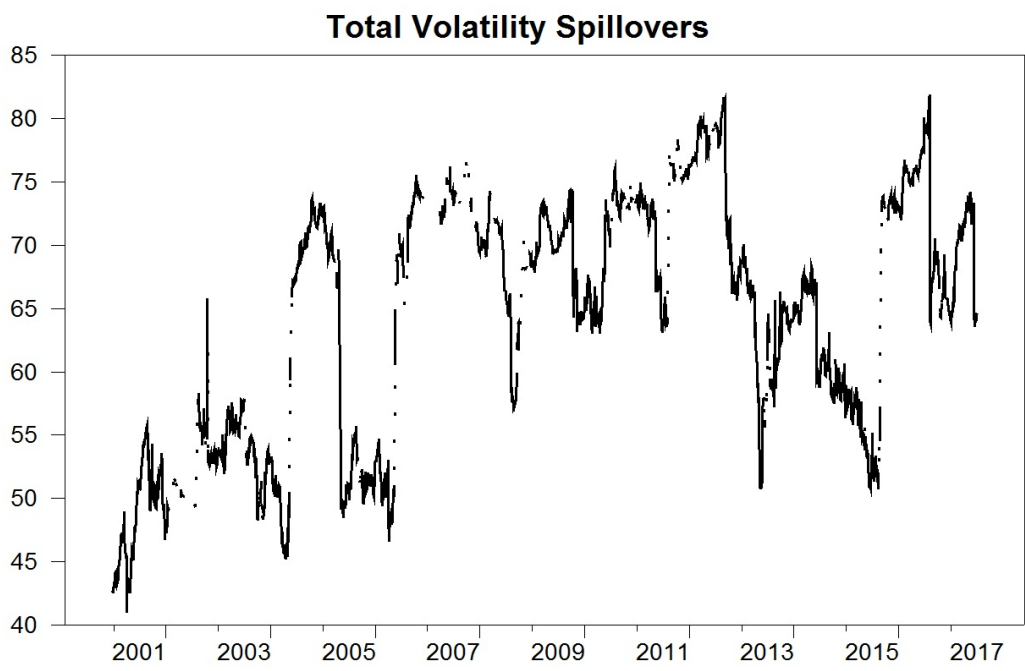

Figure 4. Total volatility spillovers. Notes: (a) The figure depicts evolution of the total volatility spillovers among the sample Asian markets; (b) Dynamic spillover index is obtained using fixed rolling window of 250 days.

\section{Net Volatility Spillovers}

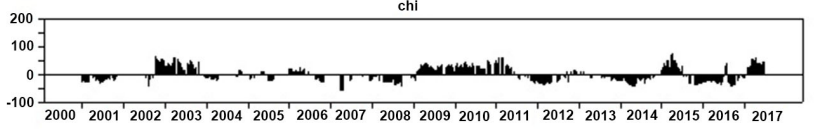

hkg

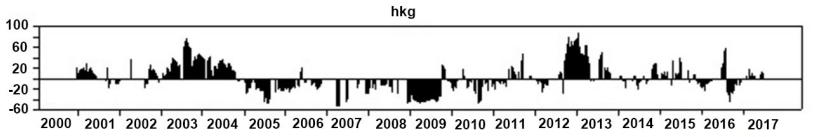

ind

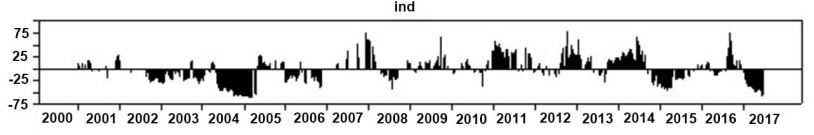

indon

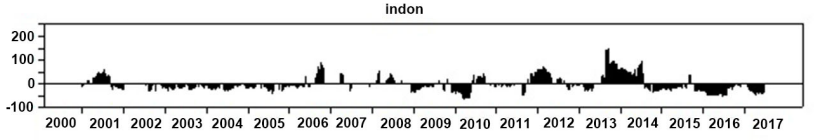

jap
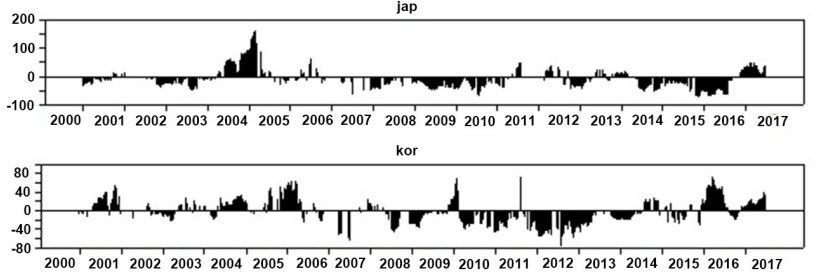

mly

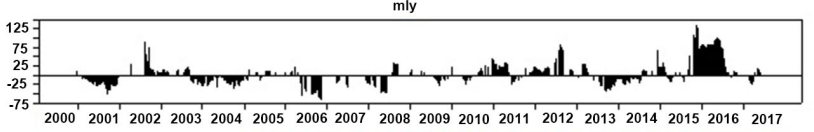

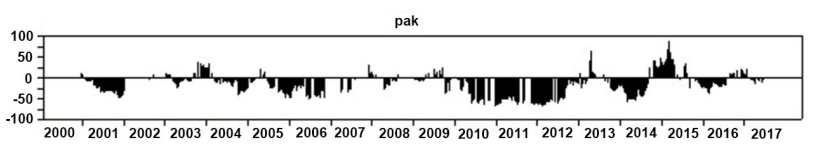
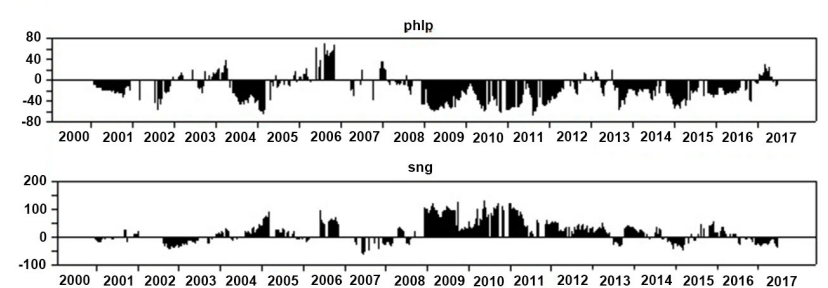

thai
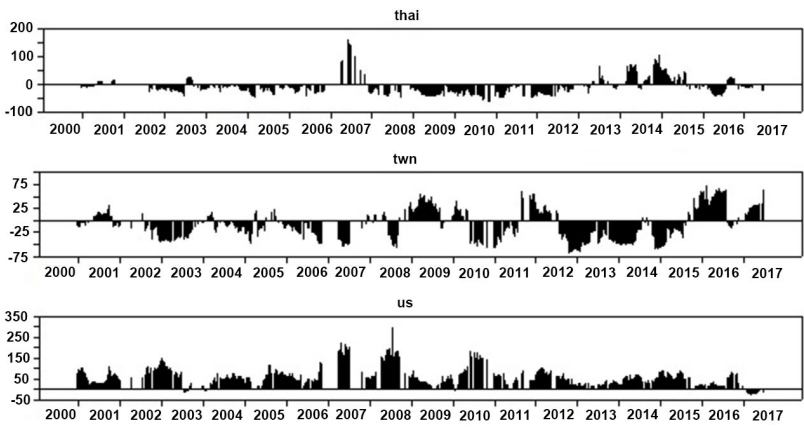

Figure 5. Net volatility spillovers. Notes: (a) The figure depicts evolution of the net volatility spillovers of the sample Asian markets; (b) Dynamic spillover index is obtained using fixed rolling window of 250 days.

area. However, India, Singapore, Taiwan China, Korea and Malaysia have net positive volatility spillovers in 2016 whereas rest have net negative value for the same period. The net return and volatility spillovers for USA are positive for en- 
tire period of study re-confirming its dominance in the global financial market system.

\section{Summary and Policy Suggestions}

This paper aims to study dynamic stock market linkages among 12 Asian countries (Chinese Mainland, Hong Kong China, Taiwan China, Japan and South Korea, India, Pakistan, Indonesia, Malaysia, Philippines, Singapore, Thailand) by examining their conditional correlations and return and volatility spillovers over the period January 3, 2000 to June 30, 2017. ADCC-GARCH model and Diebold and Yilmaz (2012) spillover index methodology have been employed to study the conditional correlations and cross-market spillovers across the sample markets, respectively. ADCC-GARCH model results reveal that Singapore has the highest correlations with the Asian markets, while Pakistan exhibits least association with the sample stock markets. Surprisingly, Japan is found to have relatively weak linkages with the Asian countries despite of having a well-developed financial system. Highest pair-wise correlation is found between Chinese Mainland and Hong Kong China. Time-varying analysis of conditional correlations suggests that associations between the Asian stock markets amplify during the Global Financial Crisis period, reflecting financial contagion. Chinese meltdown also seems to impact the Asian markets owing to their regional proximity and economic and trade relations with China as is reflected in their heightened associations during this period.

Results from Diebold and Yilmaz (2012) spillover index methodology establish highest gross return spillovers (measured as the sum of return spillovers to other markets and from other markets) as well as net return spillovers (measured as the difference between return spillovers to other markets and from other markets) for Singapore, followed by Hong Kong China and Chinese Mainland. This signifies that these markets are not only influential in transmitting spillovers to other Asian markets but also receive highest spillovers from them. Hence, they can be regarded as the dominant markets based on return spillovers. Singapore is also found to exhibit highest gross as well as net spillovers in terms of volatility spillovers. Further, India is found to be a major net transmitter of volatility spillovers to other Asian markets along with exhibiting relatively high gross spillovers. This indicates that India is a favorable destination among the global investors for risk hedging purposes. Intertemporal pattern of Dynamic return and volatility spillovers reveal that cross-market linkages intensify during the turmoil period. Overall, Diebold and Yilmaz (2012) spillover index methodology results based on return and volatility spillovers corroborate with ADCC-GARC model estimation results of highest linkages of Singapore with the sample Asian countries and time-varying pattern of linkages that amplify in the crisis periods.

Sound macroeconomic health and a robust financial system are imperative for enhancing financial integration. Hence, policymakers of the Asian region firstly need to accept the importance of enhancing their macroeconomic fundamentals. Countries need to foster investment climate and boost financial integration by 
facilitating intra-regional capital flows. Trade among the countries should be promoted by removing obstacles to cross-border transactions to reinforce the financial linkages among the countries. Further, countries need to establish a robust financial network to bring efficiency and competitiveness in their financial sectors and enhance financial integration. Advanced economies of the Asian countries that have broad and deep financial markets like Singapore, Hong Kong China, Chinese Mainland, South Korea, etc. can help the countries that are lagging behind in terms of their financial market development. Corporate governance and quality of institutions play significant role in the integration process. Hence, these economies need to focus on strengthening their governance laws and regulations and their institutional frameworks. Our suggestions are in line with empirical findings on the determinants of financial integration by [36].

Policymakers must develop a policy framework in light of the level of financial integration among the countries such that the adverse impact of any economic and financial shock is minimized. Global Financial Crisis unleashed increased volatility among the global markets and our evidence suggests that Asian markets didn't remain immune to it. Enhanced linkages among the markets during the turbulent period call for a greater policy coordination. Economies need to emphasize more strongly on regional cooperation and integration in the aftermath of the crisis that led to heightened uncertainty. Second tremor in the region came because of the growing role of China in the region which highlights the growing role of China in the region.

The study has important implications for a large number of stakeholders like international investors, policymakers and academia. It is of particular relevance to international investors in terms of devising effective portfolio strategies. India has emerged as a market conducive to risk-hedging by global investors from our empirical analysis and thus offers greater investment opportunities. Having relatively weak linkages with other Asian markets, Japanese market can confer substantial diversification gains and be a safe haven for international investors during turmoil period. For policymakers, the study provides policy suggestions to boost financial integration among the region. Further, this study enriches the existing literature on Asian financial market integration. It undertakes a comprehensive analysis of wide range of Asian markets and hence is important from the academic point of view.

\section{Conflicts of Interest}

The authors declare no conflicts of interest regarding the publication of this paper.

\section{References}

[1] Diebold, F.X. and Yilmaz, K. (2012) Better to Give than to Receive: Predictive Directional Measurement of Volatility Spillovers. International Journal of Forecasting, 28, 57-66. https://doi.org/10.1016/j.ijforecast.2011.02.006 
[2] World Bank (1993) The East Asian Miracle: Economic Growth and Public Policy. Oxford University Press, Oxford and New York.

[3] Krugman, P. (1994) The Myth of Asia’s Miracle. Foreign Affairs, 73, 62-78. https://doi.org/10.2307/20046929

[4] Berg, A. (1999) The Asia Crisis: Causes, Policy Responses, and Outcomes. IMF Working Paper. https://doi.org/10.5089/9781451855968.001

[5] World Investment Report (2017) United Nations Publication. Sales No. E.17.II.D.3.

[6] Harvey, C.R. (1993) Portfolio Enhancement Using Emerging Markets and Conditioning Information. In: Claessen, S. and Gooptu, S., Eds., Portfolio Investment in Developing Countries, The World Bank Discussion Series, The World Bank, Washington DC.

[7] Johnson, R. and Soenen, L. (2002) Asian Economic Integration and Stock Market Co-Movement. Journal of Financial Research, 25, 141-157.

https://doi.org/10.1111/1475-6803.00009

[8] Aityan, S.K., Ivanov-Schitz, A.K. and Izotov, S.S. (2010) Time-Shift Asymmetric Correlation Analysis of Global Stock Markets. Journal of International Financial Markets, Institutions \& Money, 20, 590-605. https://doi.org/10.1016/j.intfin.2010.07.006

[9] Singh, G. and Loh, L. (2010) Wavelet Perspective of Time-Varying Dynamic of Chinese, Indian and Other Major Markets. Investment Management and Financial Innovations, 7, 100-107.

[10] Syriopoulos, T. (2007) Dynamic Linkages between Emerging European and Developed Stock? Has the EMU Any Impact? International Review of Financial Analysis, 16, 41-60. https://doi.org/10.1016/j.irfa.2005.02.003

[11] Bartram, S. and Bodnar, G. (2009) No Place to Hide: The Global Crisis in Equity Markets in 2008/ 2009. Journal of International Money and Finance, 28, 1246-1292. https://doi.org/10.1016/j.jimonfin.2009.08.005

[12] Dooley, M. and Hutchinson, M. (2009) Transmission of the U.S. Subprime Crisis to Emerging Markets: Evidence on the Decoupling Hypothesis. Journal of International Money and Finance, 28, 1333-1349. https://doi.org/10.1016/j.jimonfin.2009.08.004

[13] Pesaran, B. and Pesaran, M.H. (2010) Conditional Volatility and Correlations of Weekly Returns and the VaR Analysis of 2008 Stock Market Crash. Economic Modelling, 27, 1398-1419. https://doi.org/10.1016/j.econmod.2010.07.012

[14] Assidenou, K.E. (2011) Cointegration of Major Stock Market Indices during the 2008 Global Financial Distress. International Journal of Economics and Finance, 3, 212-222. https://doi.org/10.5539/ijef.v3n2p212

[15] Chakrabarti, G. (2011) Financial Crisis and the Changing Nature of Volatility Contagion in the Asia-Pacific Region. Journal of Asset Management, 12, 172-184. https://doi.org/10.1057/jam.2011.29

[16] Arouri, A.E.H., Nguyen, D.K. and Pukthuanthong, K. (2012) An International CAPM for Partially Integrated Markets: Theory and Empirical Evidence. Journal of Banking \& Finance, 36, 2473-2493. https://doi.org/10.1016/j.jbankfin.2012.05.004

[17] Narayan, S., Sriananthakumar, S. and Islam, S.Z. (2014) Stock Market Integration of Emerging Asian Economies: Patterns and Causes. Economic Modelling, 39, 19-31. https://doi.org/10.1016/j.econmod.2014.02.012

[18] Asian Economic Integration Report (2017) The Era of Financial Interconnectedness How Can Asia Strengthen Financial Resilience? Asian Development Bank, Manda- 
luyong. https://doi.org/10.22617/TCS179038-2

[19] Park, Y.C. and Song, C.Y. (2001) Financial Contagion in the East Asian Crisis: With Special Reference to the Republic of Korea. In: Claessens, S. and Forbes, K.J., Eds., International Financial Contagion, Kluwer Academic Press, Boston, 241-265. https://doi.org/10.1007/978-1-4757-3314-3_10

[20] Jang, H. and Sul, W. (2002) The Asian Financial Crisis and the Co-Movement of Asian Stock Markets. Journal of Asian Economics, 13, 94-104. https://doi.org/10.1016/S1049-0078(01)00115-4

[21] Yang, J., Kolari, J.W. and Min, I. (2003) Stock Market Integration and Financial Crises: The Case of Asia. Applied Financial Economics, 13, 477-486. https://doi.org/10.1080/09603100210161965

[22] Worthington, A. and Higgs, H. (2004) Transmission of Equity Returns and Volatility in Asian Developed and Emerging Markets: A Multivariate GARCH Analysis. International Journal of Finance and Economics, 9, 71-80. https://doi.org/10.1002/ijfe.222

[23] Majid, M., Meera, A.K.M., Omar, M.A. and Aziz, H.A. (2009) Dynamic Linkages among ASEAN-5 Emerging Stock Markets. International Journal of Emerging Markets, 4, 160-184. https://doi.org/10.1108/17468800910945783

[24] Joshi, P. (2011) Return and Volatility Spillovers among Asian Stock Markets. SAGE Open, 1, 1-8. http://sgo.sagepub.com https://doi.org/10.1177/2158244011413474

[25] Jayasuriya, S.A. (2011) Stock Market Correlations between China and Its Emerging Market Neighbors. Emerging Markets Review, 12, 418-431.

https://doi.org/10.1016/j.ememar.2011.06.005

[26] Palamalai, S., Kalaivani, M. and Christopher, D. (2013) Stock Market Linkages in Emerging Asia-Pacific Markets. SAGE Open, 3, 1-15. https://doi.org/10.1177/2158244013514060

[27] Wang, L. (2013) Who Moves East Asian Stock Markets? The Role of the 2007-2009 Global Financial Crisis. Journal of International Financial Markets, Institutions \& Money, 28, 182-203. https://doi.org/10.1016/j.intfin.2013.11.003

[28] Jebran, K. (2014) Dynamic Linkages between Asian Countries Stock Markets: Evidence from Karachi Stock Exchange. Research Journal of Management Sciences, 3, 6-13.

[29] Narayan, S., Sriananthakumar, S. and Islam, S.Z. (2014) Stock Market Integration of Emerging Asian Economies: Patterns and Causes. Economic Modelling, 39, 19-31. https://doi.org/10.1016/j.econmod.2014.02.012

[30] Tam, P.S. (2014) A Spatial-Temporal Analysis of East Asian Equity Market Linkages. Journal of Comparative Economics, 42, 304-327. https://doi.org/10.1016/j.jce.2014.03.008

[31] Chien, M.-S., Lee, C.-C., Hu, T.-C. and Hu, H.-T. (2015) Dynamic Asian Stock Market Convergence: Evidence from Dynamic Cointegration Analysis among China and ASEAN-5. Economic Modelling, 51, 84-98. https://doi.org/10.1016/j.econmod.2015.06.024

[32] Dewandaru, G., Masih, R. and Masih, A.M.M. (2016) Contagion and Interdependence across Asia-Pacific Equity Markets: An Analysis Based on Multi-Horizon Discrete and Continuous Wavelet Transformations. International Review of Economics and Finance, 43, 363-377. https://doi.org/10.1016/j.iref.2016.01.002

[33] Kumar, A.S. and Kamaiah, B. (2017) Returns and Volatility Spillover between Asian 
Equity Markets: A Wavelet Approach. Economic Annals, 62, 63-83. https://doi.org/10.2298/EKA1712063K

[34] Jebran, K., Chen, S., Ullah, I. and Mirza, S.S. (2017) Does Volatility Spillover among Stock Markets Varies from Normal to Turbulent Periods? Evidence from Emerging Markets of Asia. The Journal of Finance and Data Science, 3, 20-30. https://doi.org/10.1016/j.jfds.2017.06.001

[35] Lee, H. and Cho, S.M. (2017) What Drives Dynamic Co-Movements of Stock Markets in the Pacific Basin Region? A Quantile Regression Approach. International Review of Economics and Finance, 51, 314-327. https://doi.org/10.1016/j.iref.2017.05.005

[36] Sehgal, S., Pandey, P. and Deisting, F. (2017) Stock Market Integration Dynamics and Its Determinants in the East Asian Economic Community Region. Journal of Quantitative Economics, 16, 389-425. https://doi.org/10.1007/s40953-017-0090-7

[37] Sehgal, S., Pandey, P. and Deisting, F. (2018) Time Varying Integration amongst the South Asian Equity Markets: An Empirical Study. Cogent Economics \& Finance, 6, Article ID: 1452328. https://doi.org/10.1080/23322039.2018.1452328

[38] Baele, L., Ferrando, A., Hordahl, P., Krylova, E. and Monnet, C. (2004) Measuring Financial Integration in the Euro Area. ECB Occassional Paper 14.

[39] Bartram, S.M., Taylor, S.J. and Wang, Y.-H. (2007)The Euro and European Financial Market Dependence. Journal of Banking \& Finance, 31, 1461-1481. https://doi.org/10.1016/j.jbankfin.2006.07.014

[40] Trichet, J.-C. (2010) State of the Union: The Financial Crisis and the ECB's Response between 2007 and 2009. Journal of Common Market Studies, 48, 7-19. https://doi.org/10.1111/j.1468-5965.2010.02091.x

[41] Angelini, P., Nobili, A. and Picillo, C. (2011) The Interbank Market after August 2007: What Has Changed, and Why? Journal of Money, Credit and Banking, 43, 923-958. https://doi.org/10.1111/j.1538-4616.2011.00402.x

[42] Cappiello, L., Engle, R.F. and Sheppard, K. (2006) Asymmetric Dynamics in the Correlations of Global Equity and Bond Returns. Journal of Financial Economics, 4 , 537-572. https://doi.org/10.1093/jjfinec/nbl005

[43] Nelson, D.B. (1991) Conditional Heteroskedasticity in Asset Returns: A New Approach. Econometrica, 59, 347-370. https://doi.org/10.2307/2938260

[44] Bollerslev, T. (1987) A Conditionally Heteroskedastic Time Series Model for Speculative Prices and Rates of Return. The Review of Economics and Statistics, 69, 542-547. https://doi.org/10.2307/1925546

[45] Samuel, R. and Engle, R.F. (1994) Hourly Volatility Spillovers between International Equity Markets. Journal of International Money and Finance, 13, 3-25. https://doi.org/10.1016/0261-5606(94)90021-3

[46] Tse, Y.K. (1999) Price Discovery and Volatility Spillovers in the DJIA Index and Futures Markets. Journal of Futures Markets, 19, 911-930. https://doi.org/10.1002/(SICI)1096-9934(199912)19:8<911::AID-FUT4>3.0.CO;2-Q

[47] Bollerslev, T. (1990) Modelling the Coherence in Short-Run Nominal Exchange Rates: A Multivariate Generalized ARCH Model. The Review of Economics and Statistics, 72, 498-505. https://doi.org/10.2307/2109358

[48] Engle, R. (2002) Dynamic Conditional Correlation: A Simple Class of Multivariate Generalized Autoregressive Conditional Heteroskedasticity Models. Journal of Business \& Economic Statistics, 20, 339-350. https://doi.org/10.1198/073500102288618487 
[49] Kim, M.H. and Sun, L. (2017) Dynamic Conditional Correlations between Chinese Sector Returns and the S\&P 500 Index: An Interpretation Based on Investment Shocks. International Review of Economics \& Finance, 48, 309-325.

https://doi.org/10.1016/j.iref.2016.12.014

[50] Koop, G., Pesaran, M.H. and Potter, S.M. (1996) Impulse Response Analysis in Non-Linear Multivariate Models. Journal of Econometrics, 74, 119-147. https://doi.org/10.1016/0304-4076(95)01753-4

[51] Pesaran, M.H. and Shin, Y. (1998) Generalized Impulse Response Analysis in Linear Multivariate Models. Economics Letters, 58, 17-29. https://doi.org/10.1016/S0165-1765(97)00214-0

[52] Endriga, B. (2017) What We Learned about Foreign Direct Investment in Asia (Part I). Asia Regional Integration Center Tracking Asian Integration.

https://aric.adb.org/blog/what-we-learned-about-foreign-direct-investment-in-asia$\underline{\text { (part-i) }}$

[53] Kim, M.S. and Wang, S. (2006) On the Application of Stochastic Volatility Models. Computational Statistics \& Data Analysis, 51, 2210-2217.

https://doi.org/10.1016/j.csda.2006.08.002 